\title{
FLEXIBLE EXCHANGE RATES IN THE 1970S
}

\author{
Jacob A. Frenkel
}

\section{INTRODUCTION}

our recent experience with a system of flexible exchange rates lad led to a renewed interest in the operations of foreign exchange narkets and in studying the principal determinants of exchange rates. The 1970s witnessed the dramatic evolution of the international monetary system from a regime of pegged exchange rates which prevailed for about a quarter of a century since the Bretton woods conference into a regime of flexible (though managed) rates. The emergence of the new legal and economic system confronted traders, national governments and international organizations with new economic problems, choices and instruments. During the 1970 s exchange rates have fluctuated widely and inflation rates accelerated. The international monetary system had to accommodate extraordinarily large oil related shocks which affected trade flows in goods and assets. Huge oil payments had to be recycled. Uncertainties concerning future developments in international politics reached new heights and the prospects for the world economy got gloomier. These developments have placed unprecedented pressures on the markets for foreign exchange as well as on other asset markets.

Dr. Frenkel is Professor of Economics at the University of Chicago and Research Associate at the National Bureau of Economic Research. The author is indebted to Lauren Feinstone for efficient research assistance and to the National Science Foundation for financial support. In revising the paper he would like to acknowledge having benefited from useful comments by Sebastian Edwards, Stanley Fischer, Craig S. Hakkio, Paul Krugman, Michael L. Mussa and Nasser Saidi. 
They have been associated with a large slide in the value of the U.S. dollar, and have resulted in speeding up the creation of new institutions like the European Monetary System which provides the formal framework for the management of exchange rates among members. The increased interdependence among countries and the recognition that exchange rate policies by one national government exert influence on other economies have also induced a legal response from international organizations. For example, in late Apri1 1977, the Executive Board of the International Monetary Fund approved the details of the second amendment to Article IV of the amended Articles of Agreement dealing with the principles and procedures for surveillance of member countries' exchange rate policies.

These developments provide the background for this paper which is intended to present a brief survey of key issues and lessons from the experience with floating rates during the 1970s. The main orientation of the paper is empirical and the analysis is based on the experience of three exchange rates: the Dollar/Pound, the Dollar/French Franc and the Dollar/DM. In the second section I analyze the efficiency of the foreign exchange markets by examining the relationship between spot and forward exchange rates; in that context $I$ also examine and interpret the extent of exchange rate volatility. The analysis of the foreign exchange markets is important because it sheds light on severa! questions like: 1) have exchange rates fluctuated "excessively?" 2) is there evidence that speculation in the foreign exchange markets is destabilizing? 3) is there evidence that there is "insufficient" speculation in the foreign exchange markets? 4) is there evidence for a market failure in the sense that there are unexploited profit 
opportunities? These issues are relevant for assessing the performance of floating rates as well as for discussing whether there is a case for government intervention in the foreign exchange markets. The analytical framework that is used for interpreting the volatility of exchange rates and the association between spot and forward rates is the modern theory of exchange rate detemination. Within this perspective exchange rates are viewed as the prices of assets that are traded in organized markets and, like the prices of other assets, are strongly influenced by expectations about future events.

The relationship between exchange rates and interest rates is analyzed in the third section from the perspective of the monetary approach to the exchange rate. This analysis is of particular relevance in view of the new policies of the Federal Reserve Board, which were announced on October 6, 1979, that are intended to curb inflation and to support the dollar. One of the key issues that is raised in this section is the distinction between anticipated and unanticipated changes in rates of interest. The policy implication of this distinction is obvious. As an analytical matter this distinction is important because the modern approach to exchange rate determination implies that exchange rates are strongly influenced by "news" which by definition is unpredicted. Therefore, unanticipated rather than anticipated changes in interest rates should have a strong effect on changes in exchange rates. This prediction is tested empirically.

The fourth section analyzes the relationship between exchange rates and prices by examining the patterns of deviation from purchasing power parties. This examination is relevant for assessing whether the flexible exchange rate system was successful in insulating national 
economies from foreign shocks, and whether it provided policymakers with an added instrument for the conduct of macroeconomic policy. The evidence on deviations from purchasing power parities is also relevant for the discussion of whether there is a case for managed float. The fifth section concludes the paper with some concluding remarks.

\section{THE EFFICIENCY OF THE FOREIGN EXCHANGE MARKET}

AND THE MOVEMENT OF EXCHANGE RATES

In this section I analyze the principal characteristics of the relationship between spot and forward exchange rates which seem to emerge from the experience of the 1970s. Following an analys is of the efficiency of the foreign exchange market I discuss the more general issues underlying the relationships between spot and forward rates and their volatility.

The Efficiency of the Foreign Exchange Market

One of the central insights of the monetary (or the asset market) approach to the exchange rate is the notion that the exchange rate, being a relative price of two assets, is determined in a manner similar to the deteraination of other asset prices and that expectations concerning future course of everts play a central role in affecting current exchange rates.

If the foreign exchange market is efficient and if the exchange rate is determined in a fashion similar to the determination of other asset prices, we should expect current prices to reflect al 1 currently

For collections of articles summarizing this approach see the Scandinavian Journal of Economics, no. 2, 1976, and Frenkel and Johnson (1978). 
avallable information. Expectations concerning future exchange rates should be incorporated and reflected in forward exchange rates. Thus, to examine the efficiency of the market, I first regress the logarithm of the current spot exchange rate, in $S_{t}$, on the logarithm of the onemonth forward exchange rate prevailing at the previous month, $x \mathrm{~F}_{t-1}$, as in equation (1). ${ }^{2}$

$$
\text { (1) } \quad \ln S_{t}=a+b \ln F_{t-1}+u_{t}
$$

If the market for foreign exchange is efficient and if the forward exchange rate is an unbiased forecast of the future spot exchange rate, then we expect that: 1) the constant term in equation (1) should not differ significantly from zero, ${ }^{3}$ 2) the slope coefficient should not differ significantly from unity and, 3) the residuals should be serially uncorrelated. I examine three exchange rates: the Dollarl Pound, the Dollar/Franc and the Dollar/DM. Equation (1) was estimated using monthly data for the pertod June 1973 - July 1979. The beginning of the period was deternined by the attempt to concentrate on the experience of the current exchange rate regime (following the initial post Bretton-woods transition period). The resulting ordinary least -

${ }^{2}$ For an application of the same methodology in analyzing the efficiency properties of the foreign exchange market during the German hyperinflation of 1921-1923 see Frenke1 (1976, 1977, 1979). For an application to other exchange rates during the 1920s, see Frenkel and Clements (1980), for an application to the 1920s and the 1970s, see krugman (1977); for an interesting analysis using time-series and crosssection data, see Bi1son (1979), for an analys is of market efficiency using novel econometric techniques, see Hakkio (1979a), and Hansen and Hodrick (1980), and for surveys, see Levich $(1978,1979)$.

3 More precisely, if (assuming risk neutrality) the forward rate measures the expected value of the future spot rate, then the constant term in the logarithmic equation (1) should be $-0.5 \sigma_{u}^{2}$; see Frenkel (1979). 
squares estimates are reported in Table 1 . Also reported in Table 1 are additional regressions which witl be analyzed shortly. As may be seen for the Dollar/DM exchange rate, the hypotheses that (at the 95 percent confidence leve1) the constant term does not differ significantly from zero and that the slope coefficient does not differ significantly from unity cannot be rejected. These hypotheses are rejected for the Dollar/Franc exchange rate and are rejected (marginally) for the Dollar/Pound exchange rate. The joint hypotheses, however, that the constant is zero and that the slope coefficient is unity cannot be rejected at the 95 percent for the Dollar/Pound and the Dollar/DM exchange rates and at the 99 percent for the Dollar/Franc exchange rate. The test statistics for testing the joint hypotheses are reported in the column headed by $F$ in Table 1 .

It was argued above that in an efficient market, expectations concerning future exchange rates are reflected in forward rates, and that spot exchange rates reflect all currently available information. If forward exchange rates prevailing at period t-1 sumarize all relevant information available at that period, they should also contain the information that is summarized in data corresponding to period $t-2$. It thus follows that including additional lagged values of the forward rates in equation (1) should not greatly affect the coefficients of determination and should not yield coefficients that differ significantly from zero. The results reported in Table 1 are consistent with this hypothesis; in all cases the coefficients of en $F_{t-2}$ do not differ significantly from zero and the inclusion of the additional lagged variabies does not improve the fit. Furthemore, in all cases the Durbin-Watson statistics are consistent with the hypothesis of the 


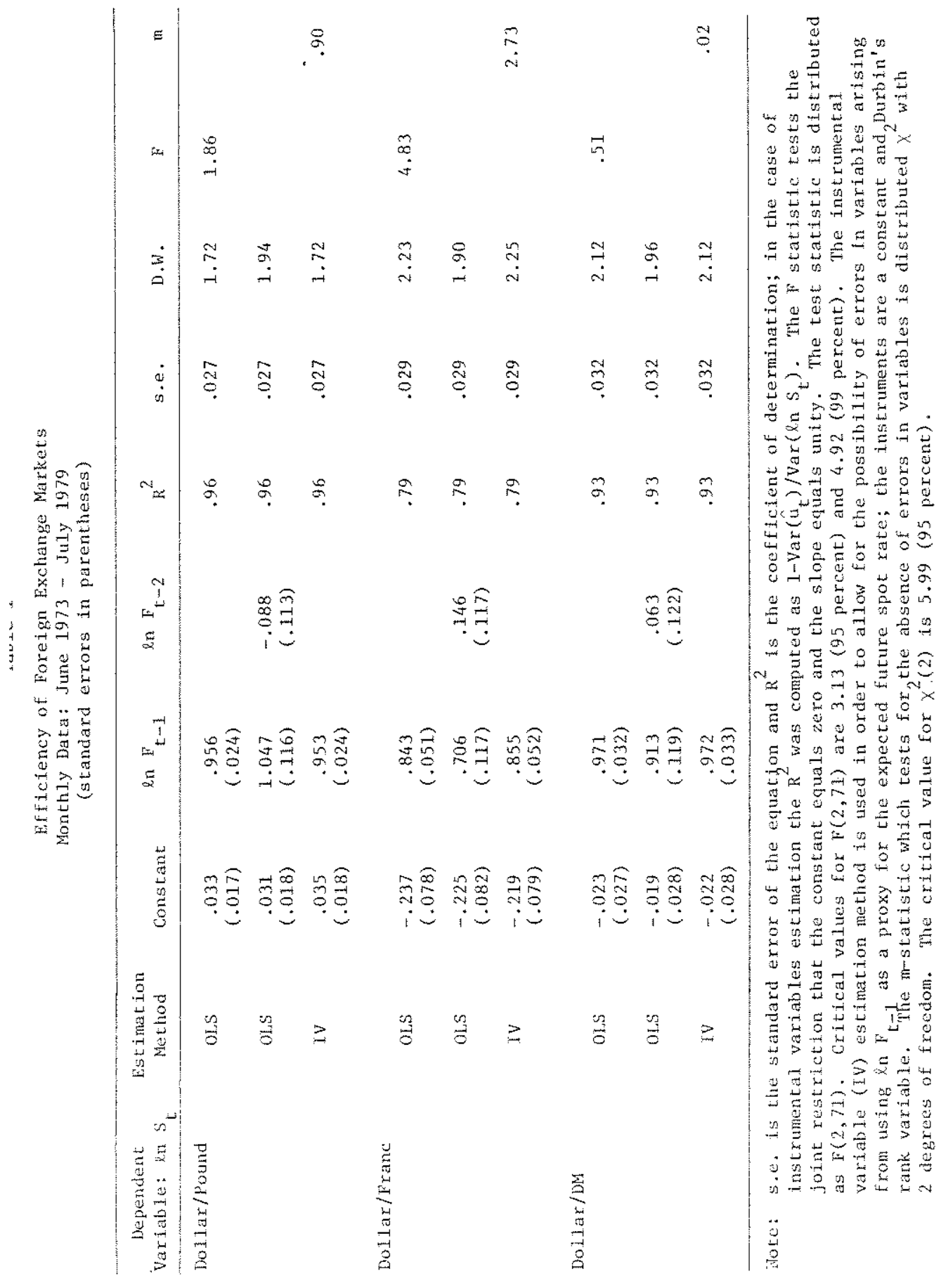

$-207-$ 
absence of first-order autocorrelated residuals and an examination of higher order correlations (up to 12 lags) shows that no correlation of any order is significant.

To further examine the relationship between the various exchange rates we note that one of the assumptions underlying equation (1) was the notion that the forward exchange rate measures the unobservable value of the expected future spot exchange rate. This assumption provided the justification for using equation (1) instead of the more fundamental relationship that is embodied in equation (2):

$$
\ln S_{t}=a+b \ln \left(S_{t}^{e} \mid t-1\right)+\varepsilon_{t}
$$

where $\left(S_{t}^{e} \mid t-1\right)$ denotes the expected spot exchange rate for period $t$ based on the information avallable at period $t-1$. If, however, the forward exchange rate at $t-1$ is a "noisy" proxy for the expected future value of the spot rate, (i.e., it measures it with a random error) then we would obtain that

$$
\ln F_{t-1}=\ln \left(S_{t}^{e} \mid t-1\right)+v_{t-1} ; E\left(v_{t}\right)=0
$$

and substituting equation (3) into equation (2) yields:

$$
\ln S_{t}=a+b \ln F_{t-1}+\left(\varepsilon_{t}-b v_{t-1}\right)
$$

In this case the error term in equation (1) would be $u_{t}=\varepsilon_{t}-b v_{t-1}$, and the assumption that the covariance between $2 n F_{t-1}$ and $u_{t}$ is zero would entail a specification error, and the application of the ordinary least-squares (OLS) procedure would yield inconsistent estimates due to the classical errors in variables bias. 
In order to examine the possibility that the OLS estimates might be subject to the errors in variables bias, one needs to test the hypothesis that $\operatorname{cov}\left(u_{t}\right.$, en $\left.F_{t-1}\right)=0$. This test follows the specification test outlined by Hausman (1978). ${ }^{4}$ To perform the test equation (1) was estimated by applying the OLS procedure as well as by using an instrumental variables (IV) estimation method. Under the nu11-hypothesis of no misspecification the oLs coefficients vector $\hat{b}_{0}$ is an efficient and an unbiased estimate of the true coefficient vector. Under the alternative hypothes is of misspecification the vector $\hat{b}_{0}$ is biased and an unbiased coefficient vector $\hat{b}_{1}$ can be obtained by applying an instrumental variables estimation procedure. The teststatistic relevant for testing the null-hypothesis can be written as

$$
m=\left(\hat{b}_{1}-\hat{b}_{0}\right)^{\prime}\left(\operatorname{var} \hat{b}_{1}-\operatorname{var} \hat{b}_{0}\right)^{-1}\left(\hat{b}_{1}-\hat{b}_{0}\right)
$$

where $\operatorname{var}\left(\hat{b}_{1}\right)$ and $\operatorname{var}\left(\hat{b}_{0}\right)$ denote the variance-covariance matrices of $\hat{b}_{\uparrow}$ and $\hat{b}_{0}$, respectively. Under the null-hypothesis $m$ is distributed (in large samples) as $x^{2}$ with two degrees of freedom. Table 1 reports the results of estimating equation (1) by applying the instrumental variables estimation method. As may be seen for all exchange rates the two vectors of coefficients $b_{1}$ and $b_{0}$ are very close to each other. For example, for the Dollar/Pound exchange rate the constants are .033 and .035 and the slopes are .956 and .953 , consequently, the resulting m statistic is .90 which is well below 5.99 -- the critical value of

\footnotetext{
${ }^{4}$ This test was recently applied by obstfeid (1978) to the analysis of the foreign exchange market during the 1970 s and by Frenkel (1980a, 1980b) to the analys is of the foreign exchange markets during the 1920s.
} 
$x^{2}(2)$ at the 95 percent confidence level. The $m$ statistics corresponding to the other exchange rates are also below this critical value. It is concluded, therefore, that the use of the forward exchange rate as a proxy for expectations does not introduce a significant errors in variables bias and thus the use of the OLS estimation procedure seems appropriate.

The efficiency of the foreign exchange market and the rationality of using data from the forward market to measure expectations can also be analyzed from a different angle. Consider equation (6):

(6) $\quad x_{t}=a_{0}+a_{1} t+\sum_{j=1}^{n} \beta_{i} x_{t-i}+\gamma_{t-1}+w_{t}$

where $x_{t}$ denotes the percentage change in the spot exchange rate (2n $\left.S_{t}-2 n S_{t-1}\right), \pi_{t-1}$ denotes the forward prenium on foreign exchange $\left(2 n F_{t-1}-2 n S_{t-1}\right)$, $t$ denotes time, $n$ denotes the number of 1 ags, and $w$ denotes an error term. If $\pi_{t-1}$ sumarizes all avallable information concerning the future evolution of the exchange rate, then given the value of the forward premium $\pi_{-1}$, the past history of the percentage change of the exchange rate should not "help" the prediction (i.e., the past history should not be viewed as Granger-causing future changes), and the joint hypotheses that $\alpha_{1}$ and $B_{j}$ are zero should not be rejected. The results of applying these tests to the three exchange rates for various number of jags are reported in Table 2 . Also reported in Table 2 are the results of testing the joint hypotheses that $\alpha_{i}$ and $\beta_{i}$ are zero and that $\gamma$, the coefficient of the forward premium, is unity. The relevant statistic for testing the null-hypothesis is an Fstatistic which is reported in Table 2. As is evident in all cases the nu11-hypothesis cannot be rejected at the 95 percent confidence level 
since the values of the various F-statistics fall well below the corresponding critical values. It is concluded, therefore, that the forward premium on foreign exchange may be viewed as a rational expectations measure of the percentage depreciation of the currency in that it incorporates the available information that is contained in the series of past depreciations.

The principal conclusions that may be drawn from the previous discussion are that the behavior of the foreign exchange market during the 1970s has been broadly consistent with the general implications of the efficient market hypothesis and that the forward exchange rate sumarizes the relevant available information concerning the future evolution of the rate.

Exchange Rate Movenent: Volatility and Predictability

In this section I analyze the volatility of exchange rates and the extent to which this volatility is predictable. To set the stage for the analysis, I present in Figure 1 the dally and quarterly percentage changes in the three exchange rates. This figure indicates that the various exchange rates have been very volatile and that the degree of volatility of day-to-day changes in the exchange rates have been extraordinarily high and has been much smaller when averaged over longer periods. Further, the standard errors of the regressions in Table 1 indicate that the forecasts of future spot exchange rates based on the forward rates are imprecise: the standard errors of the equations are about 3 percent per month.

These characteristics of price changes are typical to auction and to organized asset markets. In such markets current prices reflect 
Table 2

Test of Rationality of Forward Premium Prediction of Currency Depreciation Monthly Data, June 1973 - July 1979

\begin{tabular}{|c|c|c|c|c|c|}
\hline \multirow{2}{*}{\multicolumn{2}{|c|}{$\begin{array}{l}\text { Dependent Vartable } \\
\text { ln } \mathrm{S}_{t}-\mathrm{l}_{\mathrm{n}} \mathrm{S}_{\mathrm{t}} \\
\text { Dollar/Pound }\end{array}$}} & \multirow[t]{2}{*}{ Nul1 Hypothests } & \multirow[t]{2}{*}{ Number of Lags } & \multicolumn{2}{|c|}{ F-statistic } \\
\hline & & & & & \\
\hline & & \multirow{4}{*}{$\alpha_{1}=0, \beta_{1}=0$} & 3 & $\mathrm{~F}(4,64)$ & $=1.680$ \\
\hline & & & 4 & $F(5,62)$ & $=1.610$ \\
\hline & & & 5 & $F(6,60)$ & $=I .231$ \\
\hline & & & 6 & $F(7,58)$ & $=1.141$ \\
\hline & & \multirow{4}{*}{$\beta_{i}=0, \gamma=1$} & 3 & $F(5,64)$ & $=1.555$ \\
\hline & o. & & 4 & $F(6,62)$ & $=1.518$ \\
\hline & 1 & & 5 & $F(7,60)$ & $= \pm .207$ \\
\hline & & & 6 & $F(8,58)$ & $=1.131$ \\
\hline \multirow[t]{8}{*}{ Dollar/Franc } & \multirow{8}{*}{\multicolumn{2}{|c|}{$a_{1}=0, \beta_{i}=0, \gamma=1$}} & 3 & $F(4,64)$ & $=1.175$ \\
\hline & & & 4 & $\mathrm{~F}(5,62)$ & $=1.327$ \\
\hline & & & 5 & $F(6,60)$ & $=1.087$ \\
\hline & & & 6 & $E(7,58)$ & $=1.014$ \\
\hline & & & 3 & $F(5,64)$ & $=1.436$ \\
\hline & & & 4 & $F(6,62)$ & $=1.519$ \\
\hline & & & 5 & $\mathrm{~F}(7,60)$ & $=1.146$ \\
\hline & & & 6 & $F(8,58)$ & $=1.063$ \\
\hline \multirow[t]{8}{*}{ Dollar/DM } & \multirow{8}{*}{\multicolumn{2}{|c|}{$\alpha_{1}=0, \beta_{i}=0, \gamma=1$}} & 3 & $F(4,64)$ & $=1.123$ \\
\hline & & & 4 & $F(5,62)$ & $=1.262$ \\
\hline & & & 5 & $F(6,60)$ & $=1.321$ \\
\hline & & & 6 & $\mathrm{E}(7,58)$ & $=1.342$ \\
\hline & & & 3 & $F(5,64)$ & $=1.183$ \\
\hline & & & 4 & $\mathrm{~F}(6,62)$ & $=1.287$ \\
\hline & & & 5 & $\mathrm{~F}(7,60)$ & $=1.403$ \\
\hline & & & 6 & $(8,58)$ & $=1.525$ \\
\hline
\end{tabular}


HORT-RUN VARIABILITY IN EXCHANGE RATES IN TERMS OF U.S. DOLLARS, APRIL 2, 1973 - DECEMBER 31, 1978

(Daily percentago changes)
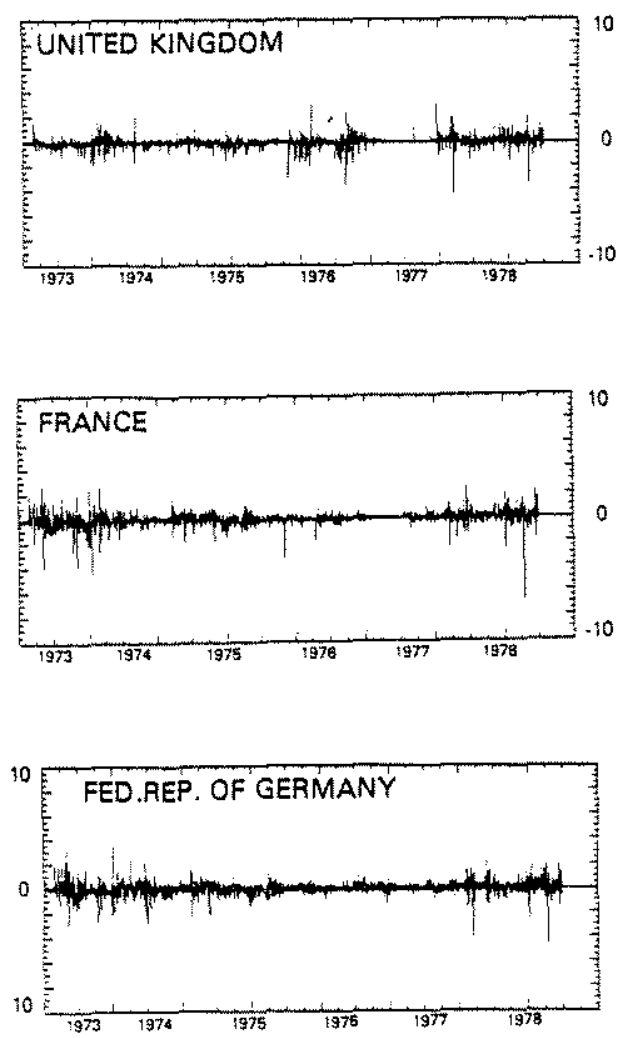

Soutce: Artus and foung (1979).
(Outartarly percentage changes]
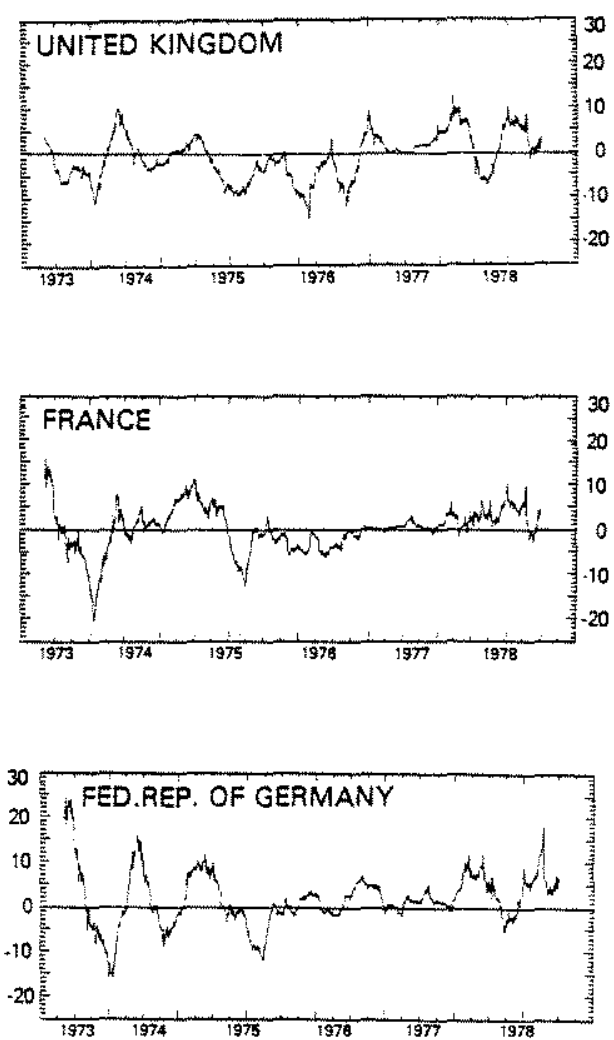
expectations concerning future course of events, and changes in expectations are inmediately reflected in corresponding changes in prices. Periods which are dominated by uncertainties, new information, rumors and announcements are likely to be periods in which changes in expectations are the prime cause of fluctuations in asset prices. Further, since the information which alters expectations must be new, the resulting fluctuations in price cannot be predicted by lagged forward exchange rates which are based on past information. ${ }^{5}$ Therefore, during such periods, one should expect exchange rates to exhibit large fluctuations and to be unbiased but inprecise forecasts of future spot rates.

To gain further insights into the implications of this perspective on the relationship between predicted and realized changes in exchange rates, I present in Figures $2-4$ plots of predicted and realized changes in exchange rates for the three pairs of currercies where the predicted change is measured by the lagged forward premium. Also presented in these figures are the differentials in national inflation rates which are discussed in the fourth section. The key fact which emerges from these figures is that predicted changes in exchange rates account for a very smal1 fraction of actual changes. 6

5 The analysis of the role of "news" in determining current exchange rates and in explaining forecast errors from the forward rate has been made forcefully by Mussa $(1976 a, 1976 b, 1977,1979 a)$. See also Dornbusch (1978). The Targe degree of volatility is a lso analyzed by Mckinnon (1976) who attributes it to insufficient speculation.

${ }^{6}$ These and the following empirical regularities are analyzed in detail in Mussa (1979a). See also Frenkel and Mussa (1980). An interesting extension would examine the relationship between the variances of predicted and actual changes in exchange rates in a manner analogous to that of Shiller (1979). 


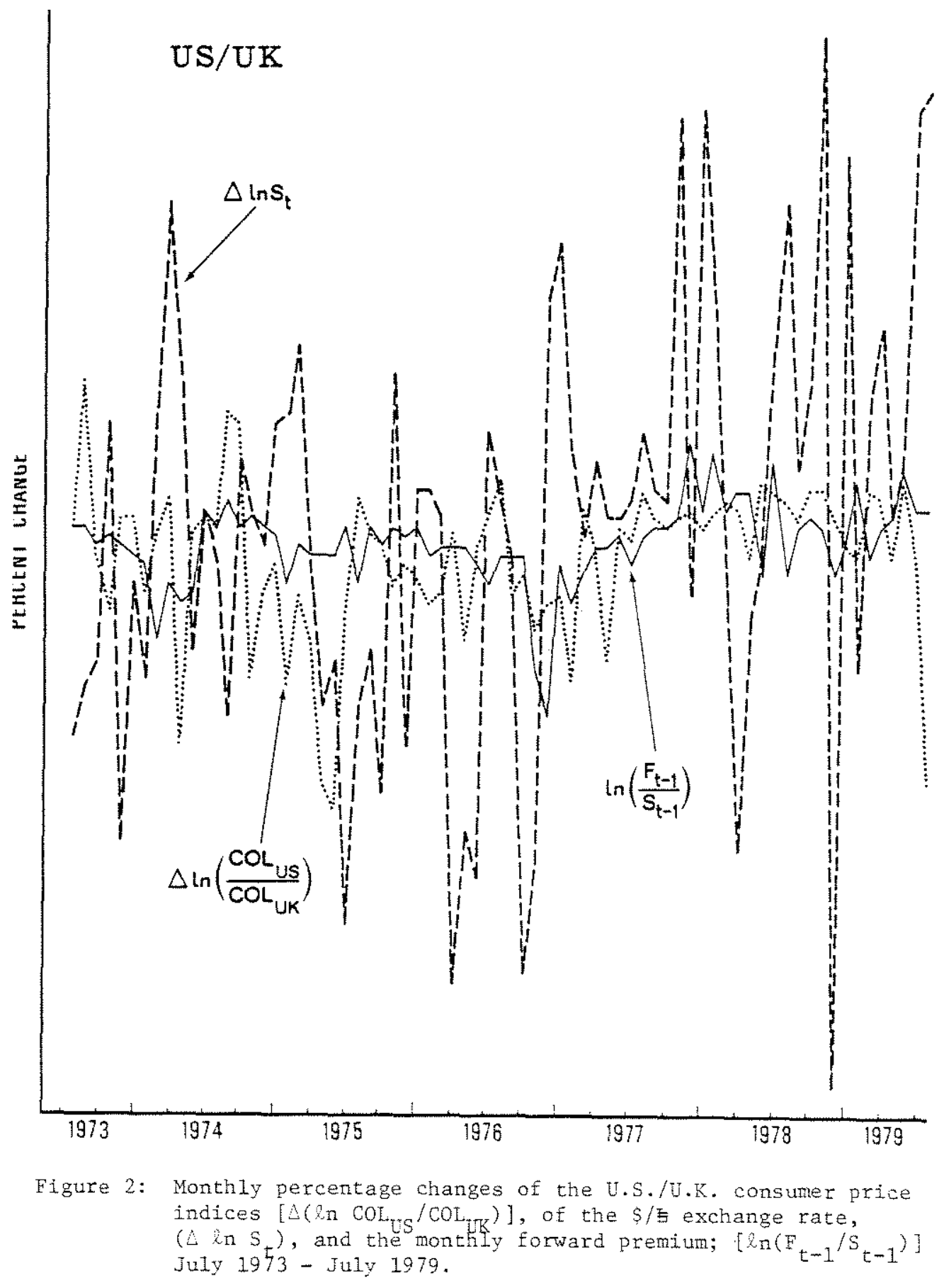




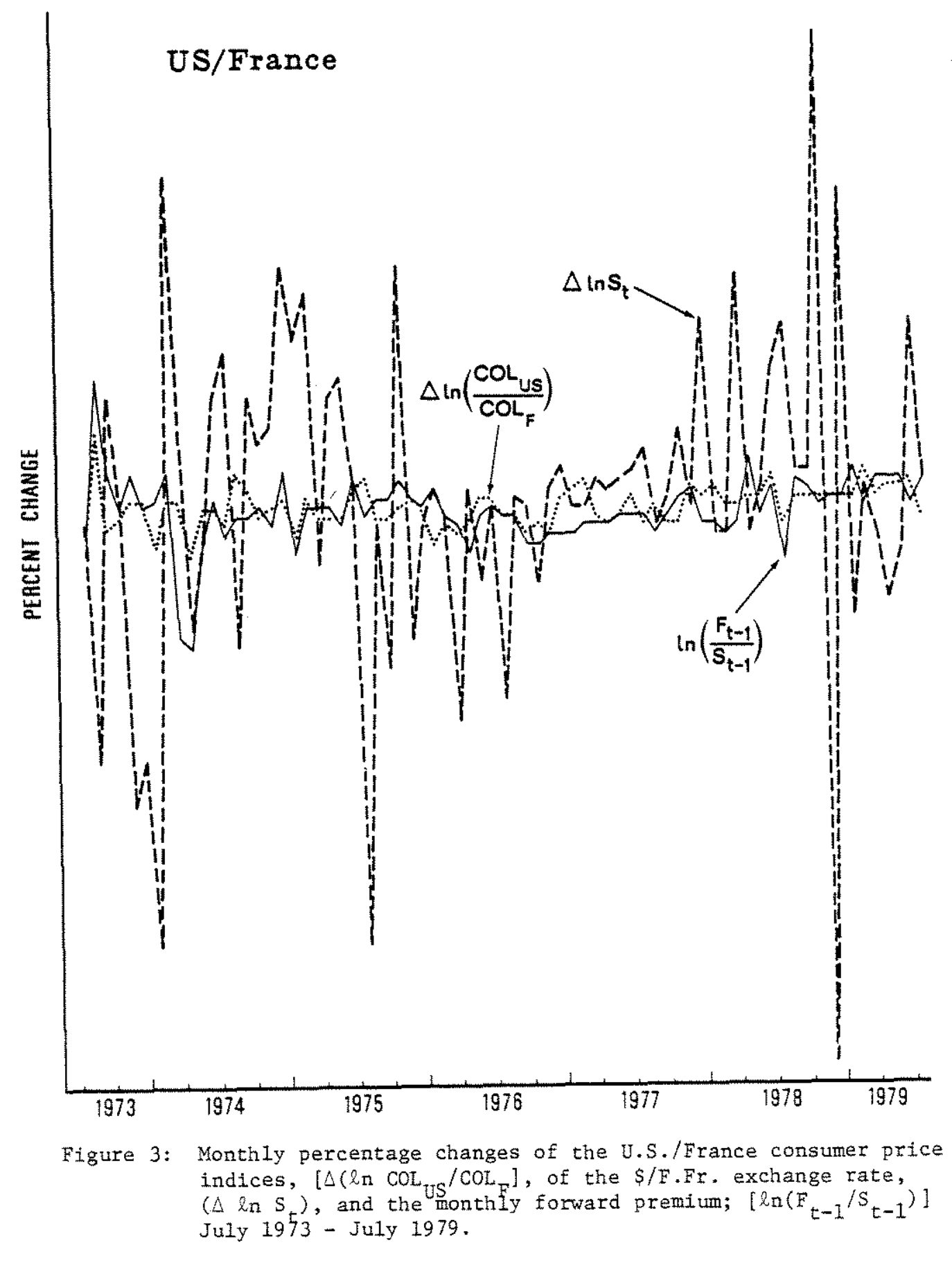

$-216-$ 


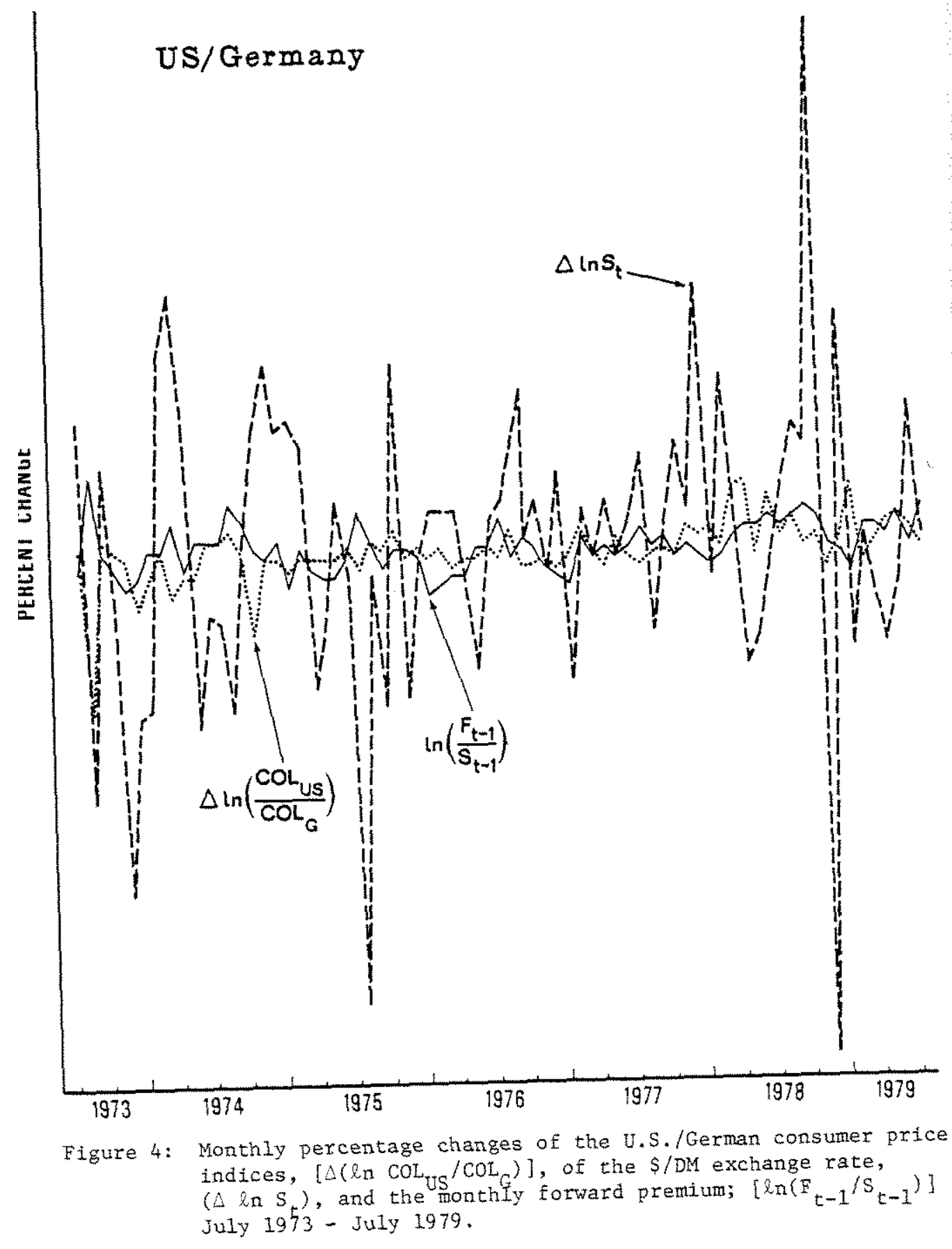

$-217-$ 
This fact suggests that the bulk of exchange rate changes seem to be due to "new information" which, by definition, could not have been anticipated and reflected in the forward premium or discount which prevailed in the previous period.

In order to examine this hypothesis, I present in Figures 5-7 plots of the spot and the contemporaneous forward exchange rates for the three pairs of currencies. Also presented are the ratios of national price levels which are discussed in the fourth section. If the dominant factor underlying changes in rates is new information, which alters views about current and expected future exchange rates by approximately the same amount, then one should expect a high correlation between movements of spot and forward rates. This fact is clearly demonstrated by Figures 5-7 where it is seen that spot and forward exchange rates tend to move together and by approximately the same amplitude (the vertical difference between the two rates correspond to the forward premium of discount on foreign exchange). The high correlation between movements in spot and forward rates is expected since the two rates respond at the same time to the same flow of new information. This characteristic is typical to the foreign exchange market as wel 1 as to other markets for stocks and durable assets. The recent pattern of gold prices provides a useful example of this general principle. Table 3 reports the spot and the future price of gold as recorded recentiy in the New York Commodity Exchange on four recent consecutive days. The two key facts which are illustrated by this table are the extent of day-to-day volatility in gold prices and the uniformity by which these changes are reflected in the price of gold for immediate delivery as well as in the prices for the twelve future delivery dates. 


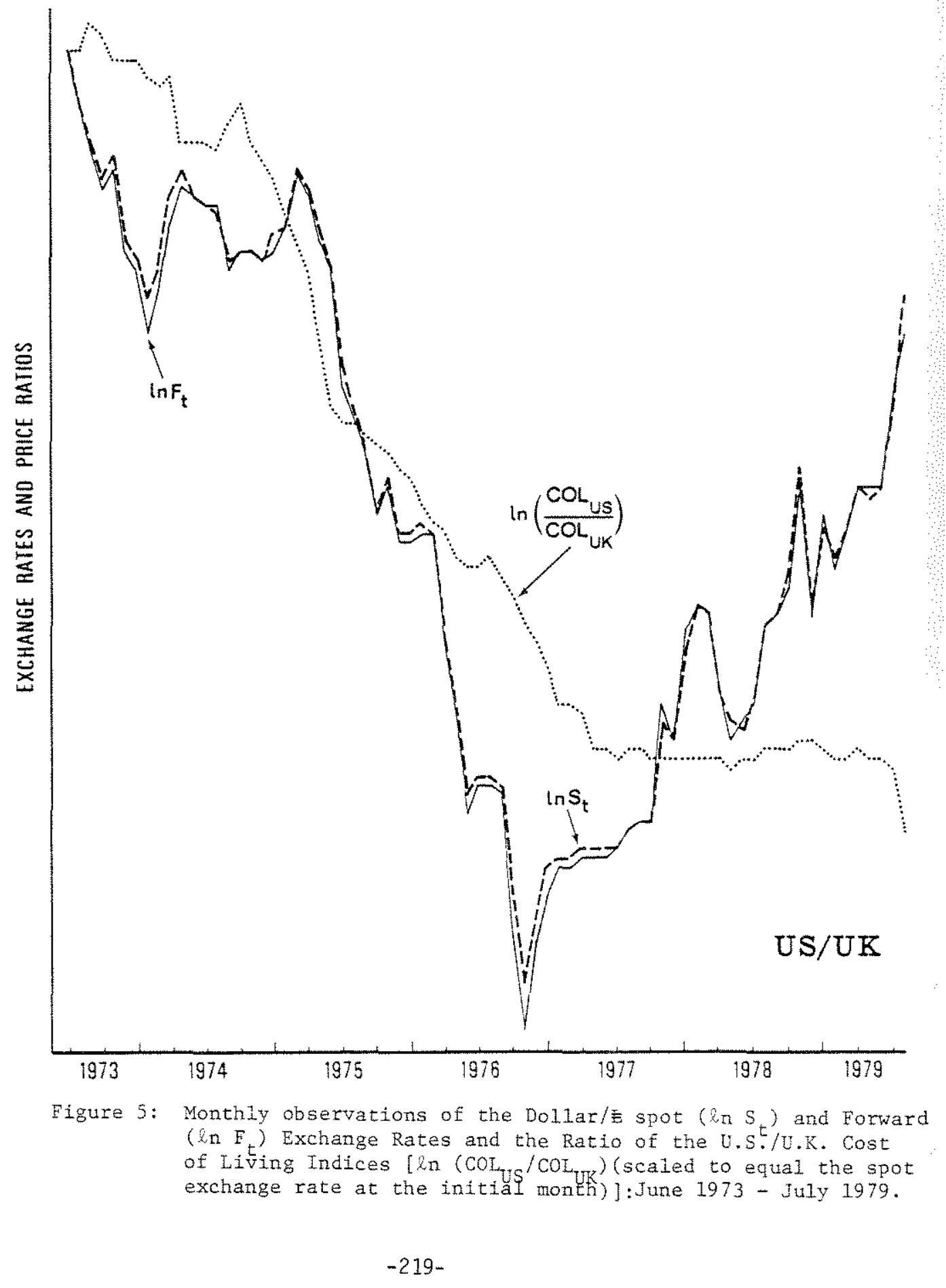




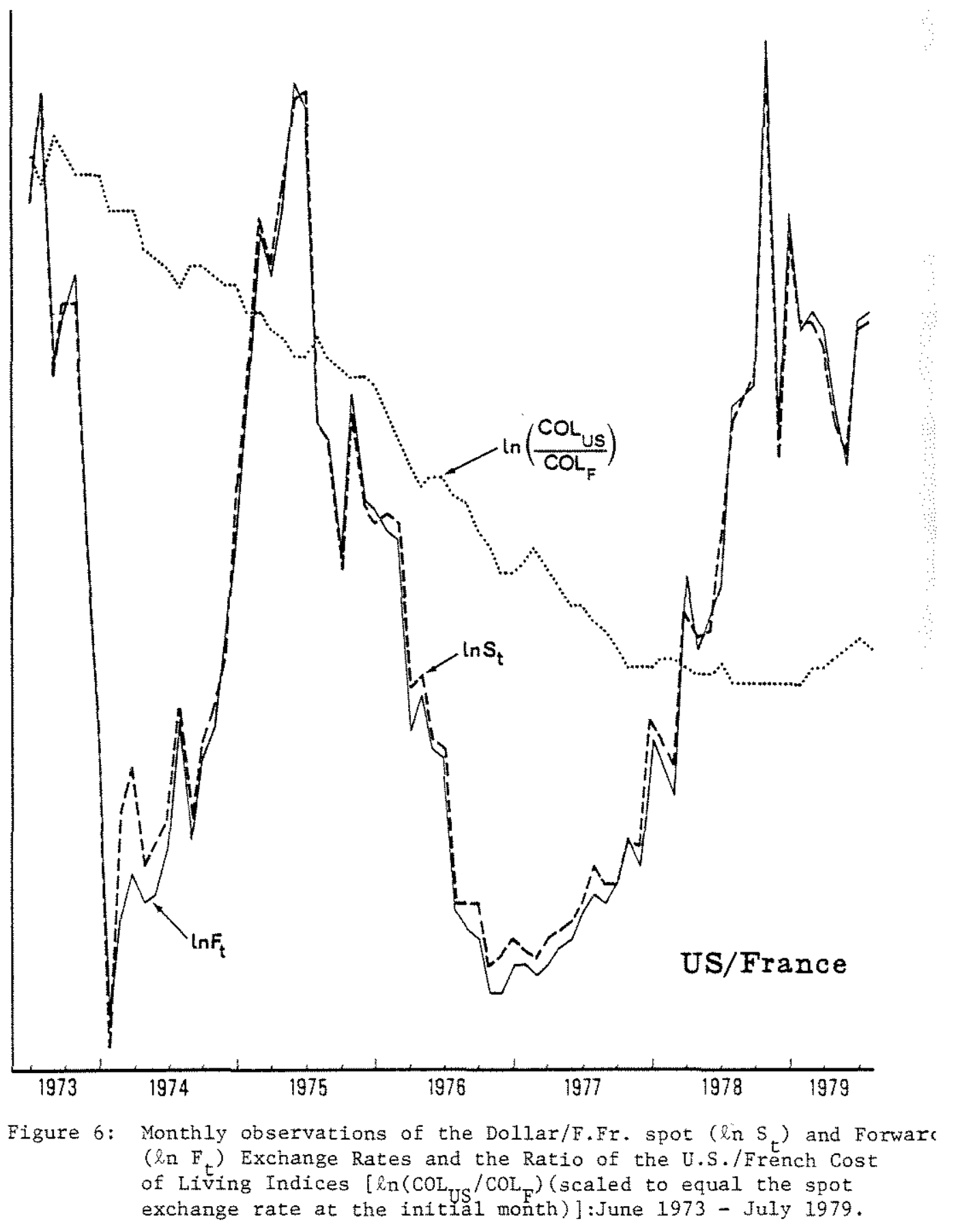




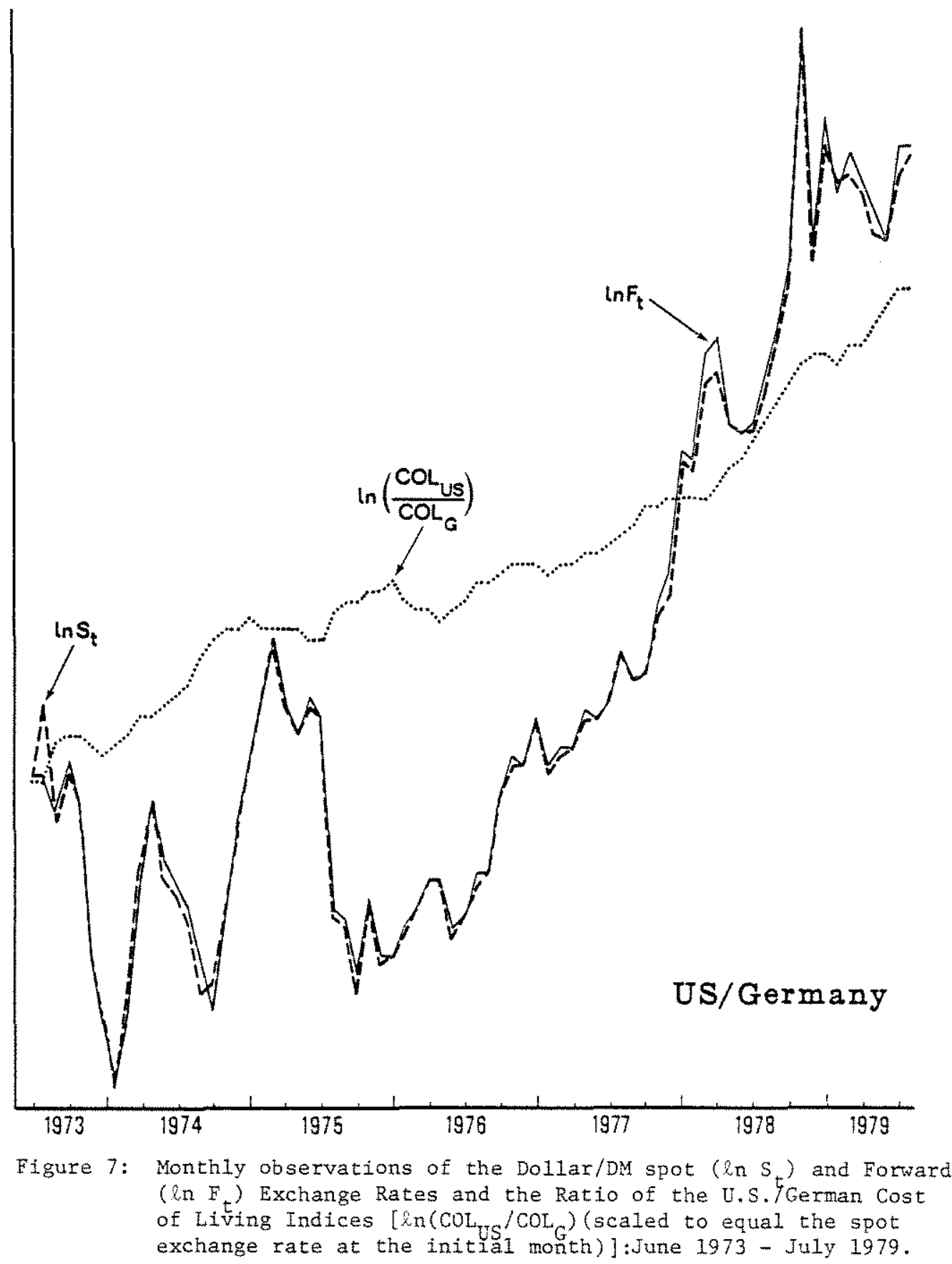

$-221-$ 


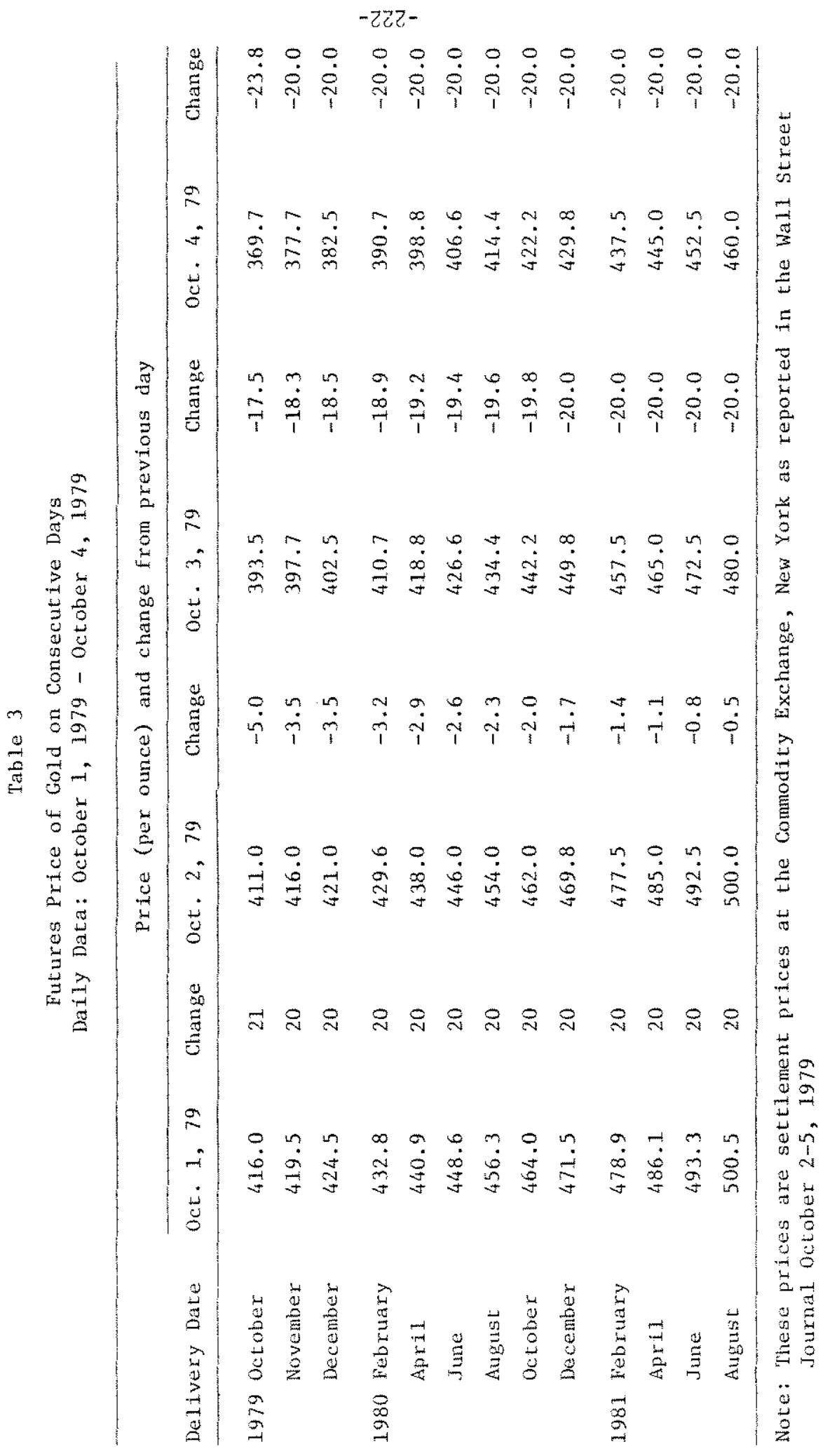


Another feature which is revealed by Figures $5-7$ is that the ontemporaneous spot and forward exchange rates are approximately equal hus indicating that the market's best forecast of the future spot rate $s$ (approximately) the current spot rate. This phenomenon reflects the act that, as an empirical matter, exchange rates have followed approximately) a random walk process. For such a process, current rices are indeed the best forecasts of future prices. To the extent hat the exchange rate had some drift, the above statement should be nterpreted in reference to that drift. This empirical phenomenon eems to correspond to the actual paths of exchange rates even though $\mathrm{t}$ does not reflect a theoretical necessity.

The final characteristic of the foreign exchange market is decribed by Figures 8-10, which plot for the three pairs of currencies he spot exchange rate and the forward premium on forward exchange. ince the units of the spot rate and the forward premium are fundalentally different, the two series were nomalized by subtracting from ach series its mean and by dividing by the corresponding standard rror. The fact which emerges from these figures is that generally though not always) there is a positive correlation between the exlected depreciation of the currency (as measured by the forward premium In foreign exchange) and the spot exchange rate. This positive corelation may be rationalized by noting that currencies which are exlected to depreciate are traded at a discount in the forward market nd, on average, these currencies also command a lower foreign exchange alue in the spot market. This correlation is interpreted further in he next section. 


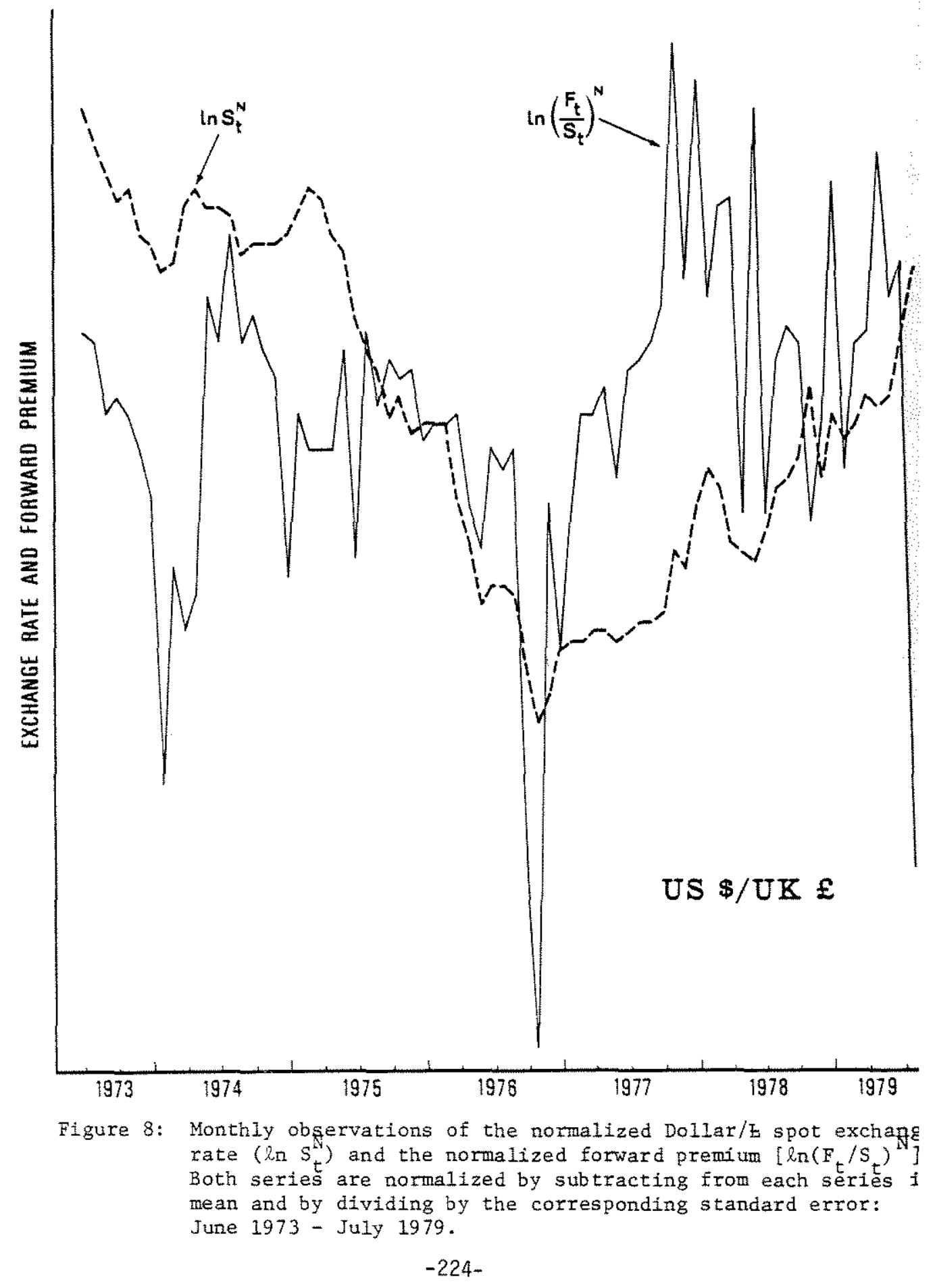




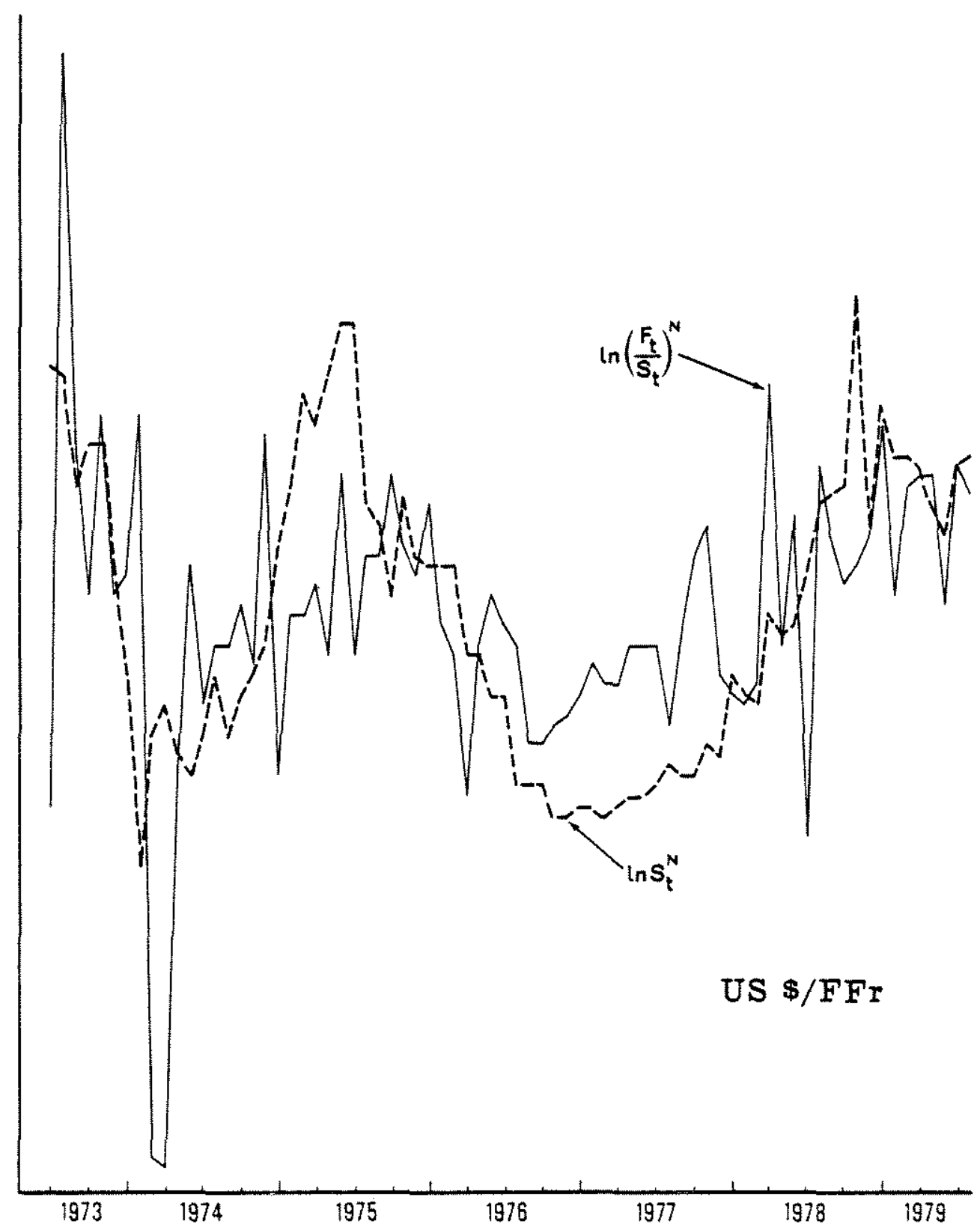

Figure 9: Monthly observationg of the normalized Dotlar/F.Fr. spot exchange race $\left(\ell_{n} S_{t}^{N}\right)$ and the normalized Forward Premitum $\left.\ln \left(F_{t} / s_{t}\right)^{3}\right]$. Both series are normalized by subtracting from each series its mean and by dividing by the corresponding standard error: June 1973 - July 1979. 


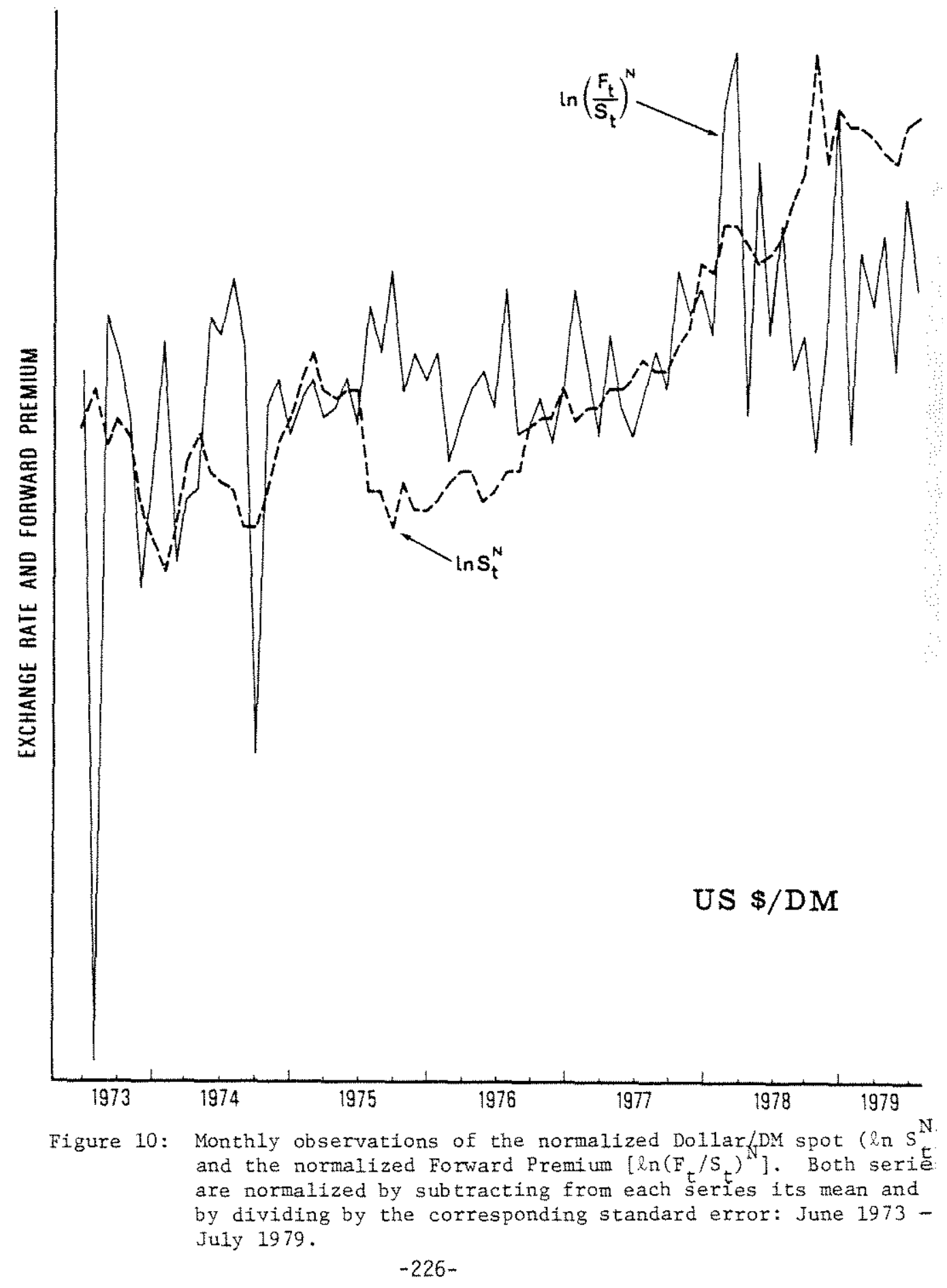




\section{EXCHANGE RATES, INTEREST RATES AND INNOVATIONS}

In this section I analyze the relationship between exchange rates and interest rates from the analytical perspective of the monetary approach to the exchange rate. To set the stage for the analytical development it is useful to recall the typical analysis which generally predicts a negative association between the rate of interest and the exchange rate. According to that analysis, a higher rate of interest attracts foreign capital which induces a surplus in the capital account of the balance of payments and thereby induces an appreciation of the domestic currency (i.e., a lower spot exchange rate). Another variant of the popular approach states that the higher rate of interest lowers spending and thus induces a surplus in the current account of the balance of payments which results in a lower spot exchange rate. A third variant of this approach claims that the higher rate of interest implies (via the interest parity theory) a higher forward premium on foreign exchange and to the extent that at a given point in time the forward exchange rate is predetermined by past history, (an assumption that is clearly rejected by the evidence on the comovements of spot and forward rates), the required rise in the forward premium will be brought about by a lower spot rate (i.e., by an appreciation of the domestic currency). Whatever the route, this approach predicts a negative relationship between the rate of interest and the spot exchange rate (or alternatively, a positive relationship between the rate of interest and the foreign exchange value of the domestic currency).

These predictions, however, do not seem to be in accord with the broad facts. Over the recent period the rise in the rate of interest in the U.S. (relative to the foreign rate of interest) has been 
Figure 11

\section{Foreign Exchange Value of the}

\section{U.S. Dollar and Interest Rate Differentials}

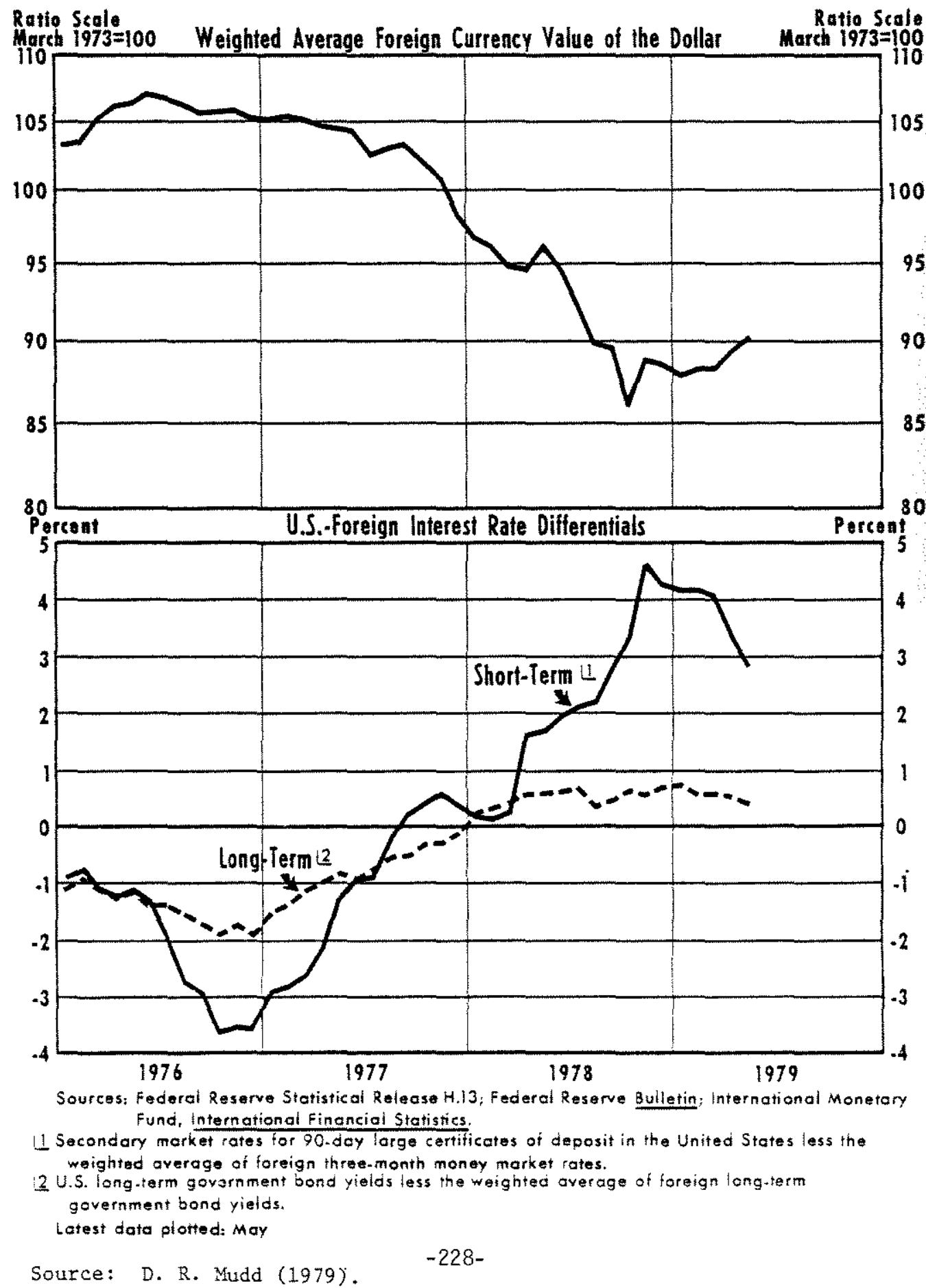


associated with a rise in the spot exchange rate (i.e., with a depreciation of the dollar). Figure 11 illustrates the point by plotting the foreign exchange value of the U.S. dollar against the interest rate differential. As is evident, in contrast with the popular prediction, the bigher (relative) rate of interest in the U.S. has been associated with a higher exchange rate (i.e., with a lower foreign exchange value of the dollar). This contradiction, however, does not arise when the exchange rate is analyzed from a monetary (or an asset market) perspective to which we now turn.

The major building blocks of the monetary approach are hypotheses concerning the properties of the demand for money and money market equilibrium and hypotheses concerning the link between domestic and foreign prices. ${ }^{7}$ Consider first the equilibrium in the money markets. The supplies of domestic and foreign real balances are $M / P$ and $M * / P *$ where $M$ and $P$ denote the nominal money supply and the price level, respectively, and where variables pertaining to the foreign country are indicated by an asterisk. Denoting the demands for real balances by $L$ and $L^{*}$ (both of which are functions which are specified below), equilibrium in the money markets is attained when
$L=M / P$ and

$$
L^{*}=M^{*} / P^{*}
$$

${ }^{7}$ For theoretical developments and applications of the approach see, for example, Dornbusch (1976a, 1976b), Kouri (1976), Mussa (1976a), Frenkel (1976), Frenkel and Johnson (1978), Frenkel and Clements (1980), Bilson (1978), Hodrick (1978), and Frankel (1979). 
From equations (7)-(8), equilibrium in the money markets implies that the ratio of the two price levels is: $\frac{P}{\bar{P} *}=\frac{M}{M *} L^{*}$

The second building block links domestic and foreign prices. Assuming the simple version of purchasing power parity implies that: 8 (10) $P=S P *$ Using equation (10) in (9) yields

$$
\text { (11) } S=\frac{M}{M * *} \frac{L^{*}}{L}
$$

Which expresses the exchange rate in terms of domestic and foreign supplies and demands for money. To gain further insight into the determinants of the exchange rate and to set the stage for the empirical estimation, assume that the demand for money depends on real income (y) and the rate of interest (i) according to:

$$
L=a y^{r} e^{-a i}
$$

${ }^{8}$ For a discussion of the choice of the relevant price index to be used in equation (10), see Frenkel (1978). This simple version of the purchasing power parity theory is used here to simplify the exposition. To the extent that there are systematic deviations from purchasing power parity they can be incorporated into the final exchange rate equam tion. Similarly, to the extent that purchasing power parities holds in the long run but not in the short run, the final exchange rate equation will reflect these dynamic characteristics. To the extent that purchasing power parity pertains to traded goods only, the exchange rate equation would also contain terms which relate to the relative prices of traded to non-traded goods; for a formulation along these lines, see Dornbusch (1976b) and for an empirical application, see clements and Frenkel (1980). A more refined specification would allow for the effects of tapiffs on the relationship between domestic and foreign prices as well as for short-run effects of unanticipated money on output rather than only on prices and the exchange rate. 


$$
L^{*}=b * y * \eta^{*} e^{-\alpha * i *}
$$

Using equations (12)-(13) in (11) and assuming for simplicity of exposition that foreign and domestic parameters of the demand for money are the same, i.e., that $\alpha=\alpha^{*}$, and that $n=n^{*}$, we obtain:

(14) $\sin S=c+\ln \frac{M}{M *}+n \ln \frac{y^{*}}{y}+a(i-i *)$

where $C \equiv \ln \left(b^{*} / a\right)$.

Equation (14) relates the exchange rate to the ratios of domestic to foreign money supplies and incomes and to the interest rate differential. 9 Most pertinent to the present purpose and in agreement with the facts summarized by Figure 11 , equation (14) yields a positive relationship between the rate of interest and the exchange rate. The economic interpretation of this association in the context of the U.S. dollar and the inflationary environment is as follows: a rise in the domestic (relative) rate of interest is primarily dominated by a rise in the expected (relative) rate of inflation which induces a decline in the demand for real cash balances; for a given path of the nominal money supply, asset market equilibrium requires a price level which is higher than the price which would have prevailed otherwise. Since the domestic price level is linked to the foreign price through some form of purchasing power parity, and since the path of the foreign price is

${ }^{9}$ It should be noted that a similar set of variables would also appear in the reduced form of a variety of alternative models. The dependence of the demand for domestic money on the domestic rate of interest and the dependence of the demand for foreign money on foreign rate of interest is assumed only for simplicity of exposition. A more general formulation would recognize that the demands for domestic and foreign monies depend on all margins of substitution. See Frenkel and Clements (1980). 
assumed to be given, the higher domestic price can only be achieved through a rise in the spot exchange rate (i.e., through a depreciation of the currency).

This explanation of the positive association between interest rates and exchange rates has an intuitive appeal in that it implies that, in an inflationary environment, a relatively rapid rise in prices is associated with high nominal rates of interest as well as with a depreciation of the currency in terms of foreign exchange. The traditional prediction of a negative relationship between interest rates and the exchange rate may, however, be reconciled with the monetary approach under the assumption that it concentrates on the short-run liquidity effects of monetary changes. Accordingly, in the short-run, a higher rate of interest may arise from tight money which induces an appreciation rather than a depreciation of the currency ${ }^{10}$ It should be emphasized, however, that during an inflationary environment llike the one prevailing in the U.S. in recent years) the variations in the rate of interest are most likely to be dominated by variations in inflationary expectations rather than by liquidity effects associated with changes in the ratio of money to bonds. In such an environment the rate of interest is expected to be positively correlated with the exchange rate. The discussion provides an illustration of the difficulties associated with using the rate of interest as the relevant monetary indicator. Traditionally, the height of the rate of interest was the

10 The short-run liquidity effects is emphasized in Dornbusch (1976b). The role of inflationary expectations in dominating exchange rate developments is emphasized in Frenke1 (1976). Frenkel (1979) and Edwards (1979) attempt to integrate these two factors. 
niterion for assessing whether monetary policy has been easy or tight: high interest rate was interpreted as indicating a tight monetary Jlicy while a low interest rate was interpreted as indicating an easy onetary policy. By now it is well recognized that during inflationary eriods it is vital to draw a distinction between nominal and real ates of interest and, as a result, during inflationary periods the ate of interest may provide a very misleading interpretation of the tance of monetary policy. The same logic applies with respect to the nalysis of the relationship between exchange rates and interest rates.

The foregoing analysis also provides the explanation for the obervation (which was noted previously) that generally there is a ositive correlation between the forward premium on foreign exchange nd the level of the spot rate. Since the spot rate is expected to be ositively correlated with interest rate differential and since, ccording to the interest parity theory, that differential must equal he forward premium on foreign exchange, it follows that the forward remium is also expected to be positively correlated with the level of he spot rate. 11 That positive correlation may also be rationalized by oting that currencies which are expected to depreciate are traded at a

${ }^{11}$ For evidence on the robustness of the interest parity relationhip, see Frenkel and Levich (1977). The positive association between he spot exchange rate and the forward premium has been interpreted in erms of an explicit monetary model. It is noteworthy that this posiive association would be predicted by any model in which current exhange rate reflects immediately the expectations of future depreciaion. See, for example, Mussa (1976a) and Frenkel and Mussa (1980). ince the rate of interest and the exchange rate are dimensionally ncommensurate, their association raise questions that are familiar rom the discussions of the Gibson Paradox. In a separate paper, I inend to examine the relationship between exchange rates and the forward remium (or the interest differential) in light of the various explanaions of the Gibson Paradox. 
discount in the forward market and, on average, these currencies also command a lower foreign exchange value in the spot market.

Prior to proceeding with the empirical evidence on the relationship between exchange rates and interest rates it might be useful to highlight some of the main features of the monetary approach which are reflected in equations (11) and (14). First, these equations demonstrate the symmetric roles that are being played by the supplies of domestic and foreign monies and the demands for these monies. Since the demands for monies depend on real variables like real incomes as we 11 as on other real variables which underlie expectations and rates of interest, it is clear that the monetary approach does not imply that the exchange rate depends only on the relative supplies of money; nor does it imply that real variables do not affect the equilibrium exchange rate. Second, from the policy perspective the monetary approach brings to the forefront the implications of the homogeneity postulate: ceteris paribus a rise in the quantity of money results in an equiproportionate $r$ ise in the exchange rate. This illustrates the intimate connection between monetary policy and exchange rate policy. Third, the positive relationship between interest rates and exchange rates and the central role played by inflationary expectations imply that policies which attempt to induce an appreciation of the currency should aim at reducing inflationary expectations. The reduction in inflationary expectations would halt the depreciation of the currency in terms of goods and in terms of foreign exchange, and would result in lower nominal rates of interest while maintaining (or even raising) real rates of interest. 
The discussion in the second section and, in particular, the conibutions by Mussa $(1977,1979 a)$ and Dornbusch (1978) emphasized that je predominant cause of exchange rate movements is news which could st have been anticipated. It was also argued in the second section lat the forward rate seems to summarize the information that is availm Jle to the market when the forward rate is being set. We may thereore express the spot rate at period $t$ as a function of factors which ave been known in advance and are summarized by the lagged forward ate, as well as a function of the "news."

15) $\ln S_{t}=a+b$ en $F_{t-1}+$ "news"

The empirical difficulty is in identifying the variable which easures the "news." Assuming that asset markets clear relatively fast nd that the "news" is immediately reflected in (unexpected) changes in he rates of interest we may write equation (15) as

16) $\ln S_{t}=a+b$ \&n $F_{t-1}+a\left[\left(i-i^{*}\right)_{t}-E_{t-1}\left(i-i^{*}\right)_{t}\right]$

here the bracketed term denotes the innovation in the interest differntial and where $E_{t-1}\left(i-i^{*}\right)_{t}$ denotes the interest differential which as expected to prevail in period $t$ based on the information available $t t-1$. The expected interest rate differential was computed from a egression of the interest differential on a constant and on two lagged alues of the differentiat. ${ }^{12}$ The previous analysis of the relationship

\footnotetext{
$12_{\text {An alternative way to compute the expected differential would }}$ se data on the term structure of interest rates. Since data on the ifferential of 2-month rates are not readily available, this computaion would require interpolations.
} 
between interest rate differential and the exchange rate implies that the coefficient $\alpha$ is expected to be positive.

Table 4 reports the 0LS astimates of equation (16) for the three exchange rates over the period June 1973-July 1979. As may be seen, in al1 cases the coefficients of the unexpected interest differential are positive and in most cases the coefficients are statistically significant. In order to verify the importance of using the series of innovations in the interest differential, Table 4 also reports estimates of regressions which replace the innovations by the actual series of the interest differential as well as regressions which include both the innovation and the actual differential. In all cases the coefficients of the actual interest differential do not differ significantly from zero. $^{13}$ To allow for a simultaneous determination of interest rates and exchange rates, equation (16) was also estimated using a two-stageleast-squares estimation procedure. These results are reported in Table 5, and again in all cases the coefficients of the unexpected interest differential are positive. These coefficients are highly significant in the Dollar/Pound exchange rate but insignificant in the other two rates. On the whole, the record shows that during the 1970s exchange rates and interest rate differential have been associated positively and thus indicating that during that inflationary period the same factors which induced a rise in the interest differential also inm duced a rise in the spot exchange rates. Furthermore, consistent with

${ }^{13}$ In order to check whether the dollar rescue policies of November 1978 have had a systematic effect on the estimates, these regressions were also estimated for the period up to september 1978. The results did not change materialiy. 


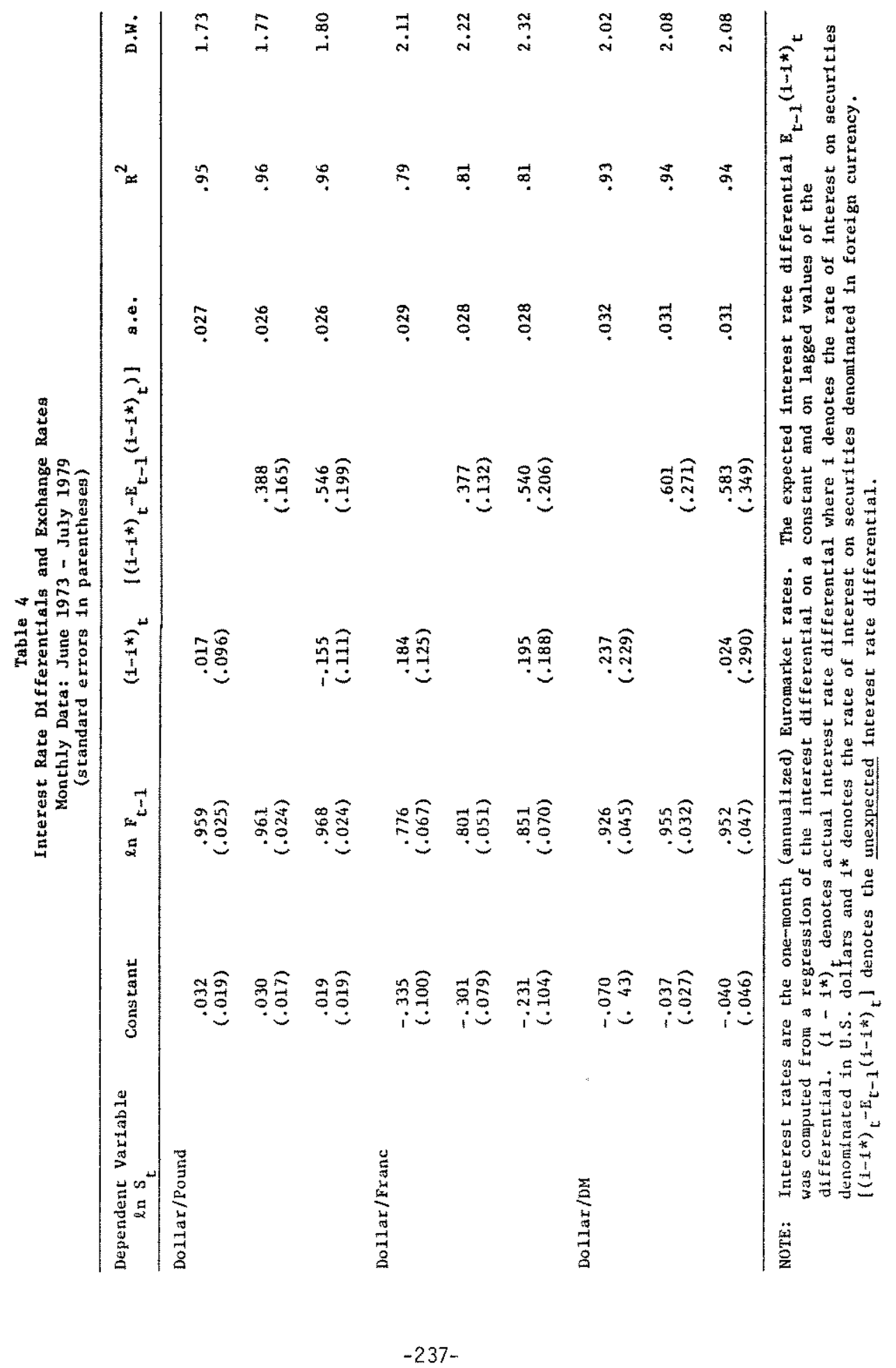


$-8 \varepsilon 2-$

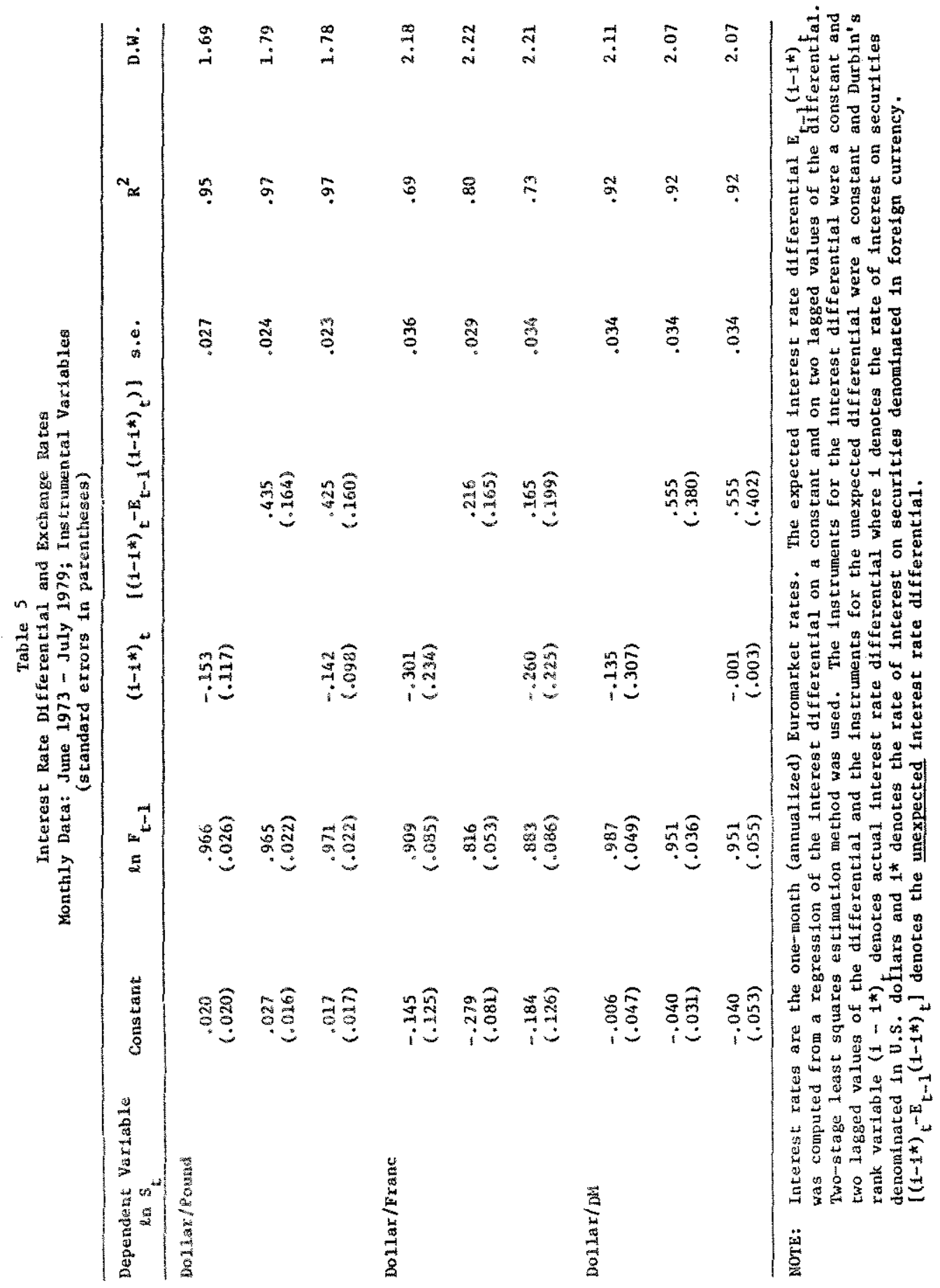


the hypothesis that current changes in exchange rates are primarily a response to new information, the eviderce shows the importance of the innovations in the interest differential.

The principle that current exchange rates already reflect expectations concerning the future course of events implies that changes in exchange rates are primarily due to innovations. In the present section this principle was appilied to the analysis of the relationship between exchange rates and interest rate differential. The principle, however, is general. For example, it fimplies that the relationship between a deficit in the balance of trade and the exchange rate depends crucially on whether the deficit was expected or not. A deficit that was expected may have no effect on the exchange rate since the latter already reflected these expectations. In contrast, an unexpected deficit in the balance of trade may contain significant new information that is likely to induce a strong effect on the exchange rate. 14

\section{EXCHANGE RATES AND PRTCES}

One of the striking facts concerning the relationship between prices and exchange rates during the 1970 s is the extent to which the evolution of prices and exchange rates have nat coincided. The originators and proponents of the purchasing power parity doctrine (Wheatley and Ricardo during the first part of the 19 th century and Cassel during the 1920s) have wiened the doctrine as an extension of the quantity

14 For a further elaboration on the relationship between exchange rates, and the current account, see Dornbusch and Fischer (1978) and Rodriguez (1978). For a special emphas is on the role of innovations in the trade batance, see Mussa (1979c) and for empirical evidence, see Hakkio (1979b). 
theory of money to the open economy. By now the consensus seems to be that purchasing power parities can be expected to hold in the long-run, if most of the shocks to the system are of a monetary origin which do not require changes in relative prices. To the extent that most of the shocks reflect "real" changes (1ike differential growth rates among sectors), the required changes in sectoral relative prices may result in a relatively loose connection between exchange rates and aggregate price levels. The experience during the l970s 117 strates the extent to which real shocks (oil embargo, supply shocks, commodity booms and shortages, differential productivity growth) result in systematic deviations from purchasing power parties. As illustrated in Figures 2-4, short-run changes in exchange rates have not been closely linked to short-run differentials in the corresponding national inflation rates, particularly as measured by consumer price indices. Furthemore, this loose link seems to be cumulative. As illustrated in Figures 5-7, divergences from purchasing power parities, neasured in terms of the relationship between exchange rates and the ratio of consumer price indices, seen to persist.

The loose link between prices and exchange rates is illustrated in Table 6 which reports the results of regressions of changes in the exchange rates on changes in (wholesale) prices. As may be seen, for the Dollar/Pound and the Dollar/Franc exchange rate, the slope coefficients are very close to unity; for the Doliar/om exchange rate the slope coefficient is less close to unity. Furthermore, in all cases the parameter estimates are extrenely imprecise. The results are even poorer when the wholesale price indices are replaced by the cost of living indices. It should be noted, however, that to some extent this 
Table 6

Relative Purchasing Power Parity; Instrumental Variables

Monthly Data: June 1973 - July 1979

(standard errors in parentheses)

\begin{tabular}{|c|c|c|c|c|}
\hline $\begin{array}{l}\text { Jependent Variable } \\
\Delta \ln S_{t}\end{array}$ & Constant & $\Delta \ln \left(\mathrm{P}_{\mathrm{W}} / \mathrm{P}_{\mathrm{W}}^{+}\right)$ & s.e. & D.W. \\
\hline Jollar/Pound & $\begin{array}{c}.003 \\
(.005)\end{array}$ & $\begin{array}{l}.999 \\
(.653)\end{array}$ & .039 & 1.71 \\
\hline Jollar/Frane & $\begin{array}{l}-.001 \\
(.004)\end{array}$ & $\begin{array}{r}.891 \\
(.682)\end{array}$ & .030 & 2.38 \\
\hline Jollar/DM & $\begin{array}{l}-.001 \\
(.008)\end{array}$ & $\begin{array}{l}1.313 \\
(2.057)\end{array}$ & .036 & 1.92 \\
\hline
\end{tabular}

fote: $\Delta$ in $S_{t}$ and $\Delta \ln \left(P_{W} / P^{*}\right)$ denote, respectively, the percentage change Ln the spot exchange rate and in the ratios of the wholesale price indices. $3 . e$. is the standard error of the regression. Two stage least-squares estimation method, is used; the instruments are a constant, time, time iquared, and lagged values of the dependent and independent variables. 
phenomenon is specific to the 1970s. During the floating rates period of the 1920s, the doctrine of purchasing power parities seems to have been much more reliable. ${ }^{15}$

The discussion in the second section emphasized that in periods which are dominated by "news," which alters expectations, exchange rates (and other asset prices) are expected to be highiy volatile. Aggregate price indices, on the other hand, are not expected to reveai such a degree of volatility since they reflect the prices of goods and services which are less durable and, therefore, are likely to be less sensitive to the news which alters expectations concerning future course of events. It follows, therefore, that in periods during which there is ample "news" which cause large fluctuations in exchange rates, there will also be large deviations from purchasing power parities. ${ }^{16}$ The different degrees of volatility of prices and exchange rates are illustrated in Table 7 , which reports the average absolute monthly percentage changes in the various exchange rates and prices. As is evident, the mean absolute change in the various spot exchange rates has been about 2 percent per month (and even slightly higher for the changes in the forward rate). The magnitudes of these changes have been more than double the magnitudes of the changes in most of the various price indices, as well as in the ratios of national price levels. For example,

${ }^{15}$ For evidence see Frenke1 (1976, 1978, 1980b) and Krugman (1978).

${ }^{16}$ On this, see Mussa (1979a). It is noteworthy that the emphas is in the text has been on the words large fluctuations; this should be contrasted with periods during which there are large secular changes in the exchange rate (1 ike the changes which occurred during the German hyperinflation). During such periods the secular changes do not stem necessarily from "news" and need not be associated with deviations from purchasing power parities. 
Table 7

Mean Absolute Petcentage Changes in Prices and Exchange Rates Monthly Data: June 1973 - July 1979

\begin{tabular}{|c|c|c|c|c|c|c|}
\hline \multirow[b]{2}{*}{ atry } & \multicolumn{6}{|c|}{ Variable } \\
\hline & WPI & COL & $\begin{array}{l}\text { Stock } \\
\text { Market }\end{array}$ & $\begin{array}{r}\begin{array}{r}\text { Excha } \\
\text { Against }\end{array} \\
\text { spot }\end{array}$ & $\begin{array}{l}\text { age Rates } \\
\text { the Dollar } \\
\text { forward }\end{array}$ & $\mathrm{COL} / \mathrm{COL}_{\mathrm{US}}$ \\
\hline * & .009 & .007 & .037 & - & - & - \\
\hline . & .014 & .012 & .066 & .021 & .021 & .007 \\
\hline nce & +011 & .009 & .054 & .020 & .021 & .003 \\
\hline many & .004 & .004 & .030 & .024 & .024 & .004 \\
\hline
\end{tabular}

e: All variables represent the absolute values of monthly percentage changes in the data. WPI denotes the wholesale price index and COL denotes the cost of living index. Data on prices and exchange rates are from the IMF tape (May 1979 version). The stock market indices are from Capital International Perspective, monthly issues. 
the mean monthly change in the cost of living price index was .4 percent in Germany, .7 percent in the U.S., .9 percent in France and 1.2 percent in the $U . K$. These differences are even more striking for the detrended series.

The notion that exchange rates have been volatile is clearly illustrated by Figures $2-4$ and by Table 7 . The comparison of the magnitudes of the changes in the exchange rates with the magnitudes of the changes in the price indices and in the ratios of national price levels may suggest, according to a narrow interpretation of the purchasing power parity doctrine, that exchange rate fluctuations have been "excessive." The previous discussion, however, has emphasized that exchange rates, being the relative prices of assets, are fundamentally different fron the price indices of goods and services and, therefore, are expected to exhibit a different degree of volatility in particular during periods that are dominated by "news." An a1ternative yardstick for measuring the degree of exchange rate fluctuations would be a comparison with prices of other assets. Indeed, while exchange rate changes have been large relative to changes in national price levels, they have been considerably smaller than changes in the prices of other assets like gold, silver, many other commodities that are traded in organized markets, and common stocks. For example, Table 7 also reports the mean absolute monthly percentage change in stock market indices. As may be seen, the mean monthly change in these indices ranged from over 3 percent in Germany to over 6 percent in the U.K. By these standards it is difficult to argue that exchange rates have been excessively volatile. 
The fundamental difference between the characteristics of exchange rates and national price levels is also reflected in their time series properties. The monthly changes in exchange rates exhibit little or no serial correlation while national price levels do exhibit a degree of serial correlation. The serial correlation of national price levels has been rationalized in recent macroeconomic theorizing in terms of costs of price adjustment, the existence of nominal contracts, confusion between relative and absolute prices and confusion between pemanent and transitory changes. This djfference between the time series properties of exchange rates and prices is reflected in the low correlation between the practically random month-to-month exchange rate changes and the serially correlated differences between national rates of inflation.

Given the short-run deviations from purchasing power parities, it is relevant to explore whether these deviations tend to diminish with time or tend to persist or even grow in size. In order to examine the patterns of the deviations, I have computed the autocorrelation functions and the partial autocorrelation functions of these deviations for the wholesale and the cost of living price indices. The deviation from purchasing power parities during month $t$ is denoted by $\Delta$ and is defined as:

(17) $\Delta_{t}=\ln S_{t^{*}}-\ln (P / P \star)_{t^{*}}$

Figures 12-14 17 lustrate the patterns of the deviations for the three exchange rates. As may be seen, the general pattern is very similar for the three exchange rates and for the two price indices. In all cases the autocorrelation function tails off at what seems to be an 
Figure 12

The Dollar/Potnd: Deviations from PPP with wholesale Price Indices

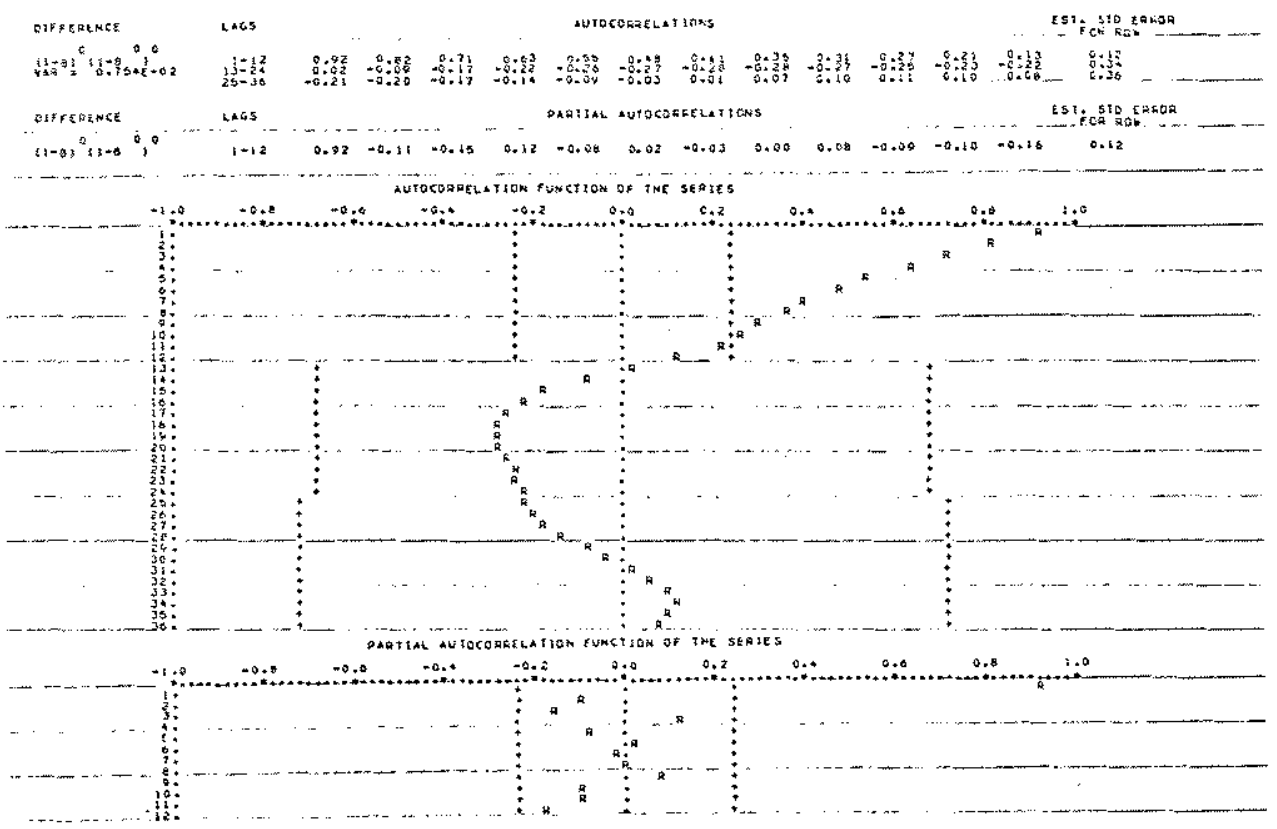

The Dollar/Pound: Deviations from PPP with Cost of Living Indices

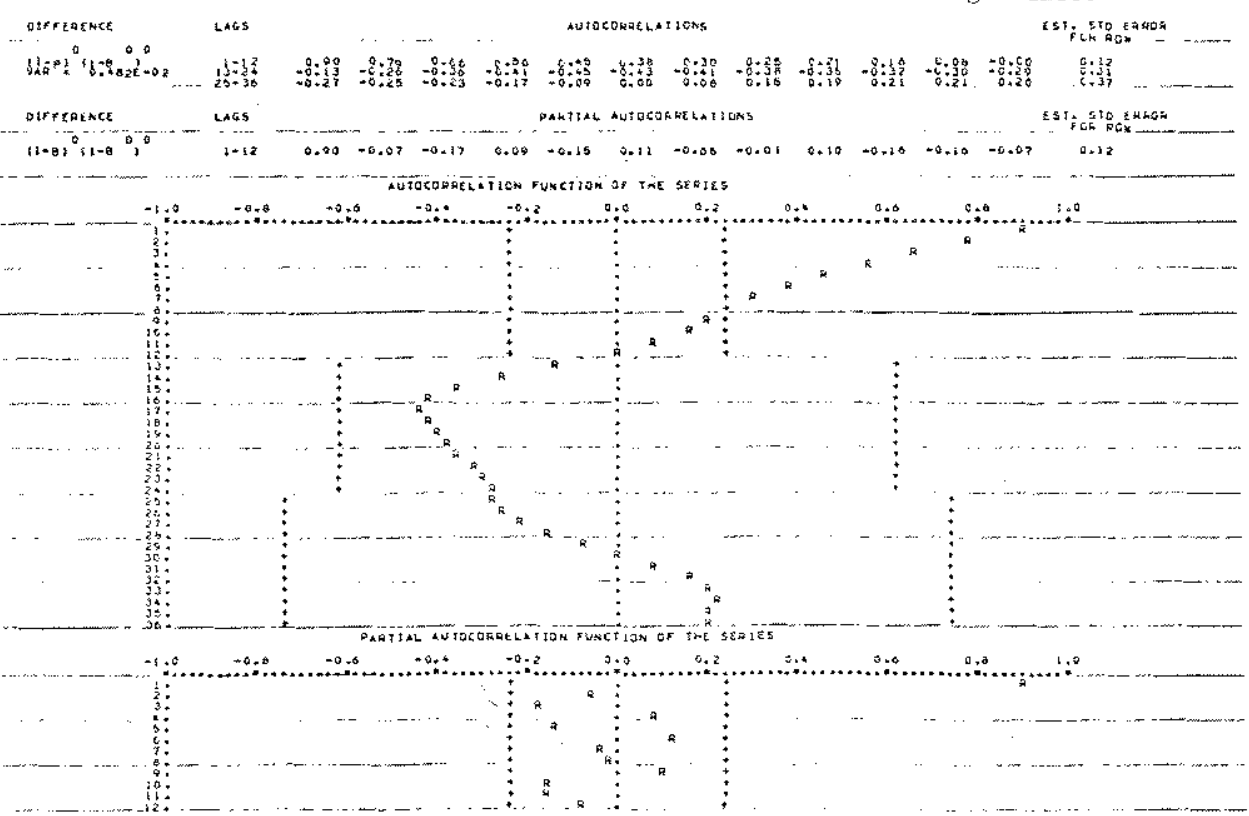


Figure 13

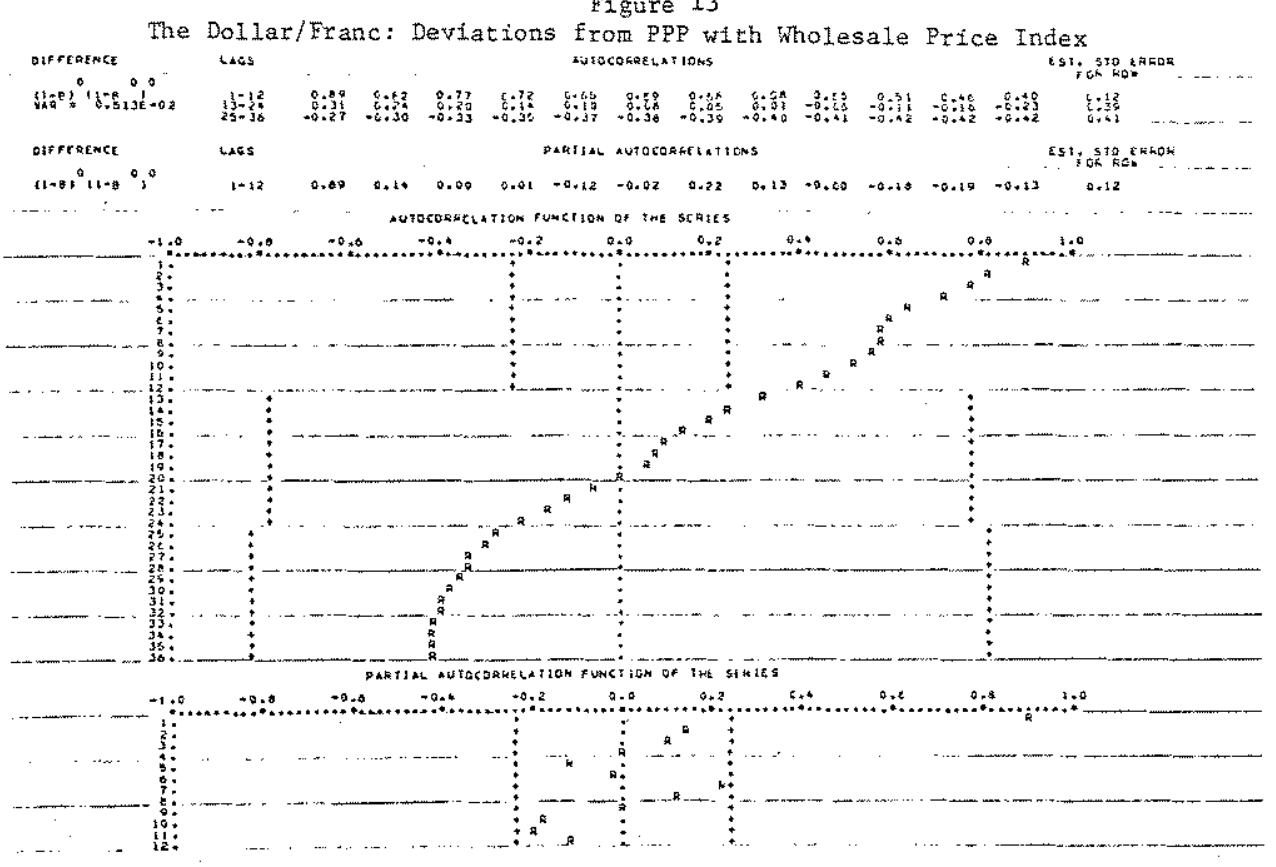

The Dollar/Franc: Deviations from PPP with Cost of Eiving Indices

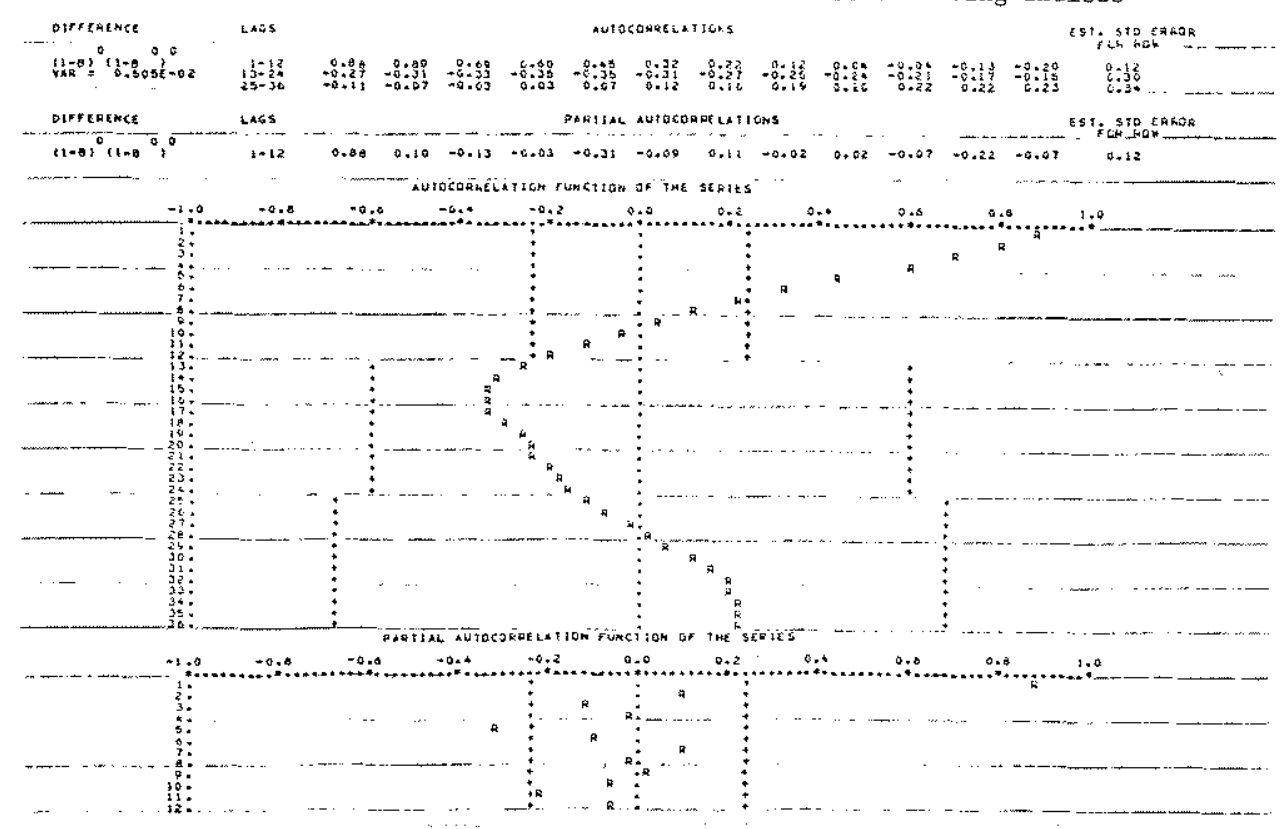


Figure 14

The Dollar/DM: Deviations from PPP with Wholesale Price Indices

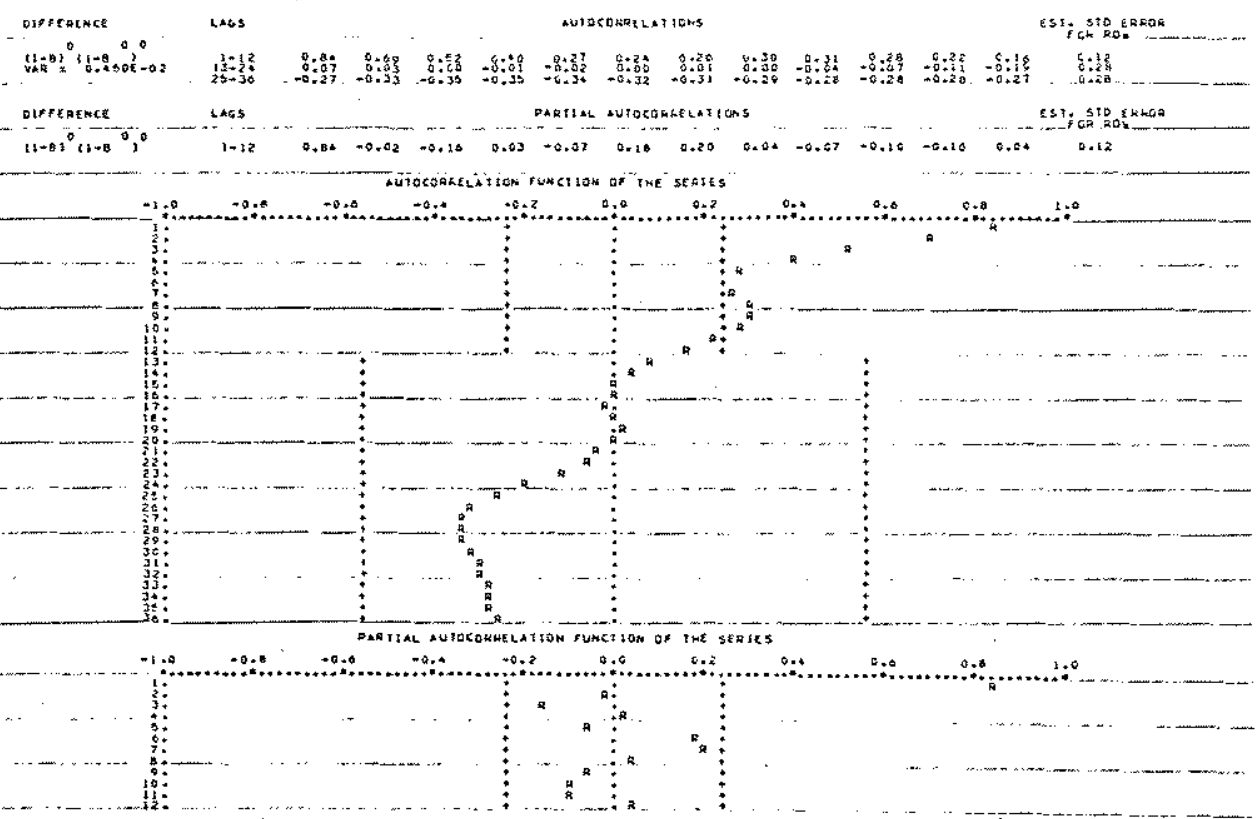

The Dollar/DM: Deviations from PPp with Cost of Living Indices

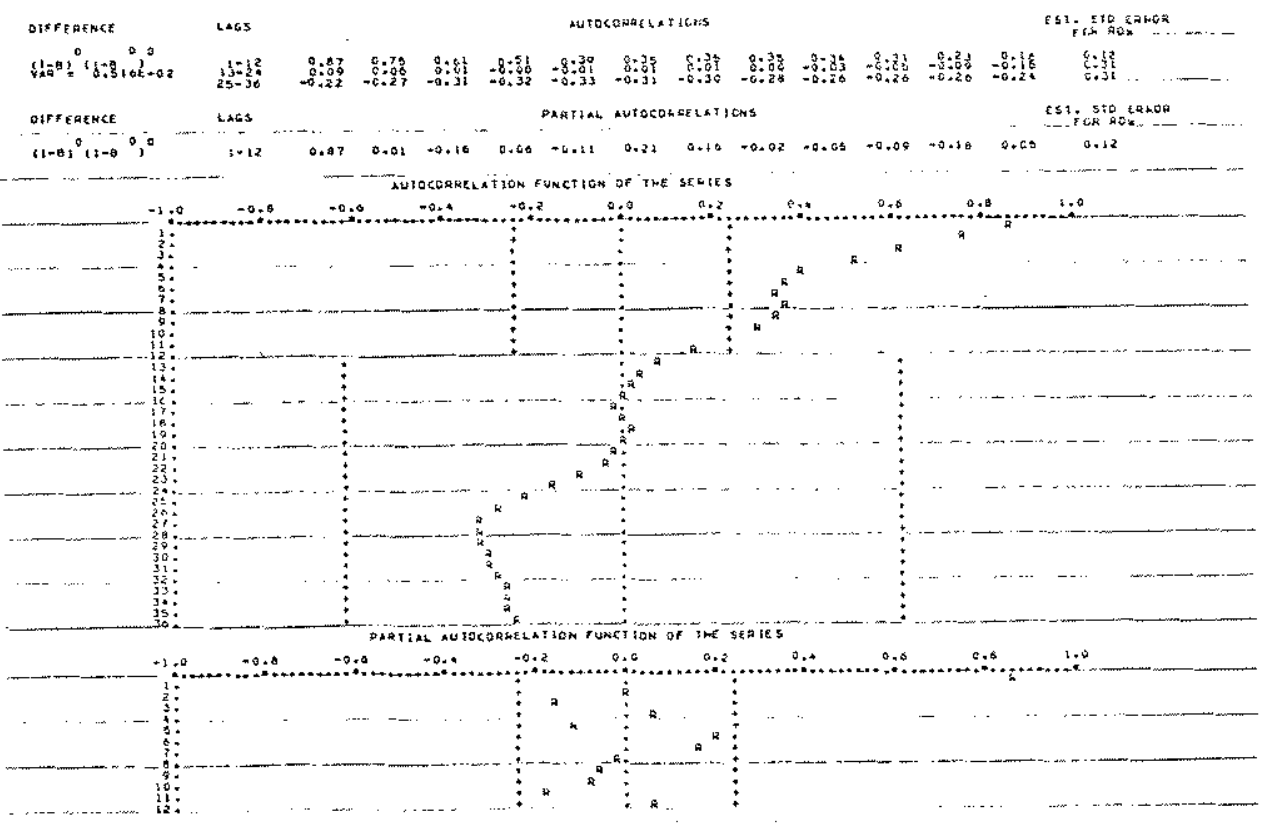


exponential rate and, in all cases, the partial autocorrelation function shows a spike at the first lag. This pattern seems to indicate (as might have been expected on the basis of the time series properties of exchange rates and price indices) that the deviations from purchasing power parities follow a first order autoregressive process. It is noteworthy, however, that in all cases the value of the autorearession term is about 0.9, indicating the possibility that the series may not satisfy the stationarity requirement. To allow for this possibility, I have also examined the autocorrelation functions and the partial autocorrelation functions of $\Delta_{t}-\Delta_{t-1}$, i.e., of the first difference of the deviations from purchasing power parities. The results indicate that these differences are serially uncorrelated, thus implying that the deviations $\Delta_{t}$ follow a random walk process. 17 In view of this possibility, I conclude that the deviations from purchasing power parities seem to follow a first order autoregressive process but that the data do not provide sufficient evidence to reject the alternative hypothesis of a random walk. Finally, it may be noted that the main difference between accepting the $A R(1)$ rather than the random walk hypothes is relates to the economic interpretation of the two alternative processes. The random walk process implies that deviations from purchasing power parities do not tend to diminish with the passage of time while the stable $A R(1)$ process implies that there are mechanisms which operate to ensure that in the long-run purchasing power parities

17 If the deviations follow a random walk process, then they do not entail (ex ante) unexploited profit opportunities. For an analys is of equilibrium deviations from purchasing power parities, see Saidi (1977). 
are satisfied. For the purpose of forecasting the near future, however, there is a very little difference between using the $A R(1)$ process with an autoregressive coefficient of 0,9 and using the random walk process.

\section{CONOUDTNG REMARKS}

In this paper I examined some aspects of the operation of flexible exchange rates. The analysis was based on the experience of the 1970s. The principle conclusions which may be drawn from the empirical work are:

(1) In spite of the extraordinary turbulence in the markets for foreign exchange, it seens that to a large extent the markets have operated efficiently. It should be noted, however, that in this context the concept of "efficiency" is somewhat narrow in that it only refers to the rotion that the markets do not seen to entail unexploited profit opportunities. A broader perspective should deal with the social cost of volatility in terms of the interference with the efficiency of the price system in guiding resource allocation, as well as with the cost of alternative outlets for the disturbances that are currently reflected in the volatility of exchange rates.

(2) The high volatility of exchange rates (spot and forward) reflect an intrinsic characteristic of the relative price of monies and other assets. The price of gold and the price of stocks as well as exchange rates between national manies depend critically on expectations concerning future course of events, and adjust rapidly in response to new information. In this 
perspective the exchange rate (in contrast with the relative price of national outputs) is being viewed as a financial variable.

(3) During infiationary periods variations in nominal rates of interest are dominated by changes in inflationary expectations; as a result, high nominal rates of interest are expected to be associated with high exchange rates (a depreciated currency). This relationship was demonstrated within the analytical framework of the monetary approach to the exchange rate, and was supported by the empirical work. In this context the key finding was the dependence of exchange rate changes on the changes in the rates of interest. This finding is in accord with the analytical prediction that current exchange rates al ready reflect current expectations about the future while changes in the current exchange rates primarily reflect changes in these expectations which, by definition, arise from new information.

(4) The experience of the 1970 s does not support the predictions of the simple version of the purchasing power parity doctrine which relates the values of current prices to current exchange rates. The empirical work showed that deviations from purchasing power parities can be characterized by a first order autoregressive process.

One of the key anaiytical insights that is provided by the monetary (or the asset market) approach to the exchange rate is that exchange rates reflect not only current circumstances but also those circumstances which are expected to 
prevail in the future. This anticipatory feature of the exchange rate (which is emphasized by Mussa, 1979b) does not characterize (at least to such a degree) the prices of national outputs. As a result, during periods which are dominated by frequent changes in expectations about the future, one may expect to find frequent deviations from purchasing power parities when the latter are computed using current prices. 18

${ }^{18}$ This phenomenon was recognized by Gustav Cassel -- the most recognized proponent of the purchasing power parity doctrine. Since this paper was prepared for presentation on Dctober 20, 1979 -- the date of Cassel's birthday (Cassel was born on 0ctober 20, 1866) it seems appropriate to conclude with the quote that reflects this key idea.

The international valuation of the currency will, then aenerally show a tendency to anticipate events, so to speak, and become more an expression of the internal value that the currency is expected to possess in a few months, or perhaps in a year's time (Casse1, 1930, pp. 149-50). 
1. Exchange Rates

The spot exchange rates are end-of-month rates obtajned from the IMF tape (May 1979 version, updated to July 1979 using the November 1979 issue of the International Financial Statistics) obtained from the International Monetary Fund. The forward exchange rates are end-of-month rates for one month maturity. The forward rates for the U.K. Pound and the DM for the period June 1973 - June 1978 are bid prices obtained from the International Money Market (IMM). For the period July 1978 - July 1979 they are sell prices obtained from the Wall Street Journal. The forward rates for the French Franc for the period June 1973July 1974 are bid prices calculated from the Weekly Review publication of the Harris Bank which reports the spot rate and the forward premium; in each case the closest Friday to the end of the month was chosen. For the period August 1974 - June 1978 the rates are bid rates obtained from the IMM and for the period July 1978 - July 1979 they are se11 prices obtained from the Wall Street Journal.

2. Prices

The wholesale and cost of living price indices are period averages obtained from the IMF tape, 1 ines 63 and 64 , respectively.

3. Rates of Interest

A11 interest rates are 1-month Eurocurrency rates obtained from the Weekly Review of the Harris Bank. In all cases the figures used correspond to the last Friday of each month.

\section{Stock Markets}

The stock market indices correspond to the last trading day of the month. The sources are Capital International Perspective, Geneva, Switzerland, monthly issues. 
REFERENCES

Artus, Jacque R. and John H. Young, "Fixed and Flexible Exchange Rates: A Renewal of the Debate," National Bureau of Economic Research, working Paper Series, no. 367, 1979.

Bilson, John F. 0., "Rational Expectations and the Exchange Rate." In J. A. Frenkel and H. G. Johnson (eds.), The Economics of Exchange Rates: Selected Studies. Reading, Mass: Addison-Wesley, 1978.

., "The "Speculative Efficiency" Hypothesis." Unpublished manuscript, University of Chicago, 1979.

Cassel, Gustav. Money and Foreign Exchange After 1919. London: Macmillan, 1930.

Clements, Kenneth W. and Jacob A. Frenkel, "Exchange Rates, Money and Relative Prices: The Dollar-Pound in the 1920s." Journal of International Economics, 10, 1980, forthcoming.

Dornbusch, Rudiger (1976a) "Capital Mobility, Flexible Exchange Rates and Macroeconomic Equilibrium." In E. Classen and P. Salin (eds.) Recent Issues in International Monetary Econonics. Amsterdam: North-Holland, 7976, Pp. 29-48.

- (1976b) "The Theory of Flexible Exchange Rate Regimes and Macroeconomic Policy." Scandinavian Journal of Economics 78, No.2 (May 1976): 255-75. Reprinted in J. A. Frenkel and H. G. Johnson (eds.), The Economics of Exchange Rates: Selected Studies. Reading, Mass.: Addison-Wes Jey, 1978.

. "Monetary Policy Under Exchange Rate Flexibility," in Managed Exchange-Rate Flexibility: The Recent Experience, Federal Reserve Bank of Boston Conference Series, No. 20, 1978, Pp. 90122 .

Dornbusch, Rudiger and Stanley Fischer, "Exchange Rates and the Current Account, " unpublished manuscript, Massachusetts Institute of Technology, 1978.

Edwards, Sebastian, "A Simple Monetary Model of Exchange Rate Determination in the Short Run - Some Preliminary Results for the Peruvian Experience 1950-1954." unpublished manuscript, University of Chicago, 1979.

Franke1, Jeffrey. "Or the Mark: The Theory of Floating Exchange Rates Based on Real Interest Differential." American Economic Review, 69. No. 4 (September, 1979): 610-22. 
Frenkel, Jacob A. "A Monetary Approach to the Exchange Rate: Doctrinal Aspects and Empirical Evidence. "Scandinavian Journal of Economics 78, No. 2 (May 1976): 200-24. Reprinted in J. A. Frenke] and H. G. Johnson (eds.), The Economics of Exchange Rates: Selected Studies. Reading, Mass.: Addison-Wesley, 1978.

., "The Forward Exchange Rate, Expectations and the Demand for Money: The German Hyperinflation. "American Economic Review 64, No. 4 (September 1977): 653-70.

. "Purchasing Power Parity: Doctrinal Perspective and Evidence from the $1920 \mathrm{~s}$. "Journal of International Economics 8 , No. 2 (May 1978): 169-9?.

., "Further Evidence on Expectations and the Demand for Money during the German Hyperinflation." Journal of Monetary Economics, 5, No. 1 (February, 1979): $81-96$.

(1980a) "The Forward Premium on Foreign Exchange and Currency Depreciation During the German Hyperinflation, "Anerican Economic Review 67, 1980, forthcoming.

(T980b) "Exchange Rates, Prices and Money: Lessons from the

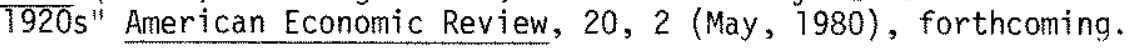

Frenkel, Jacob $A$. and Kenneth $W$. Clements, "Exchange Rates in the 1920s: A Monetary Approach" in June M. Flanders and Assaf Razin (eds.), Development in an Inflationary World, New York: Academic Press, 1980, forthcoming.

Frenke1, Jacob A. and Harry G. Johnson (eds.), The Economics of Exchange Rates: Selected Studies. Reading, Mass.: Addison-Wesley, 1978.

Frenkel, Jacob A. and Richard M. Levich, "Transaction Costs and Interest Arbitrage: Tranquil Versus Turbulent Periods." Journal of Political Economy 85, No. 6 (December, 1977): 1209-1226.

Frenke1, Jacob A. and Michael L. Mussa, "Efficiency of Foreign Exchange Markets and Measures of Turbulence," American Economic Review, 70,2 (May, 1980) forthcoming.

Hakkio, Craig S. (1979a) "Expectations and the Foreign Exchange Market." Unpublished Ph. D. Dissertation, University of Chicago, 1979.

(1979b) "Exchange Rate and Innovations in the Current Account," Unpublished manuscript, Northwestern University, 1979.

Hansen, Lars P. and Robert J. Hodrick, "Predictors of Future Spot Rates: An Economic Analysis," Journal of Political Economy 88, 4 (August, 1980) forthcoming.

Hausman, Jerry A. "Specification Tests in Econometrics." Econometrica, 46 (Novermber, 7978 ): 1251-71. 
Hodrick, Robert J. "An Empirical Analysis of the Monetary Approach to the Determination of the Exchange Rate. " In J. A. Frenkel and H.G. Johnson (eds.), The Economics of Exchange Rates: Selected Studies. Reading, Mass.: Addison-Wesley, 1978.

Kouri, Pentti, 3. S. "The Exchange Rate and the Balance of Payments in the Short Run and in the Long Run: A Monetary Approach." Scandinavian Journal of Economics 78, No. 2 (May 1976) : 280-304.

Krugman, Paul. "The Efficiency of the Forward Exchange Market: Evidence from the Twenties and the Seventies. "Unpublished manuscript, Yale University, 1977

., "Purchasing Power Parity and Exchange Rates." Journal of International Economics 8 (August, 1978): 397-407.

Levich, Richard M. "Further Results on the Efficiency of Markets for Foreign Exchange" In Managed Exchange Rate Flexibility: The Recent Experience, Federal Reserve Bank of Boston, Conference Series, No. 20, 1978.

., "The Efficiency of Markets for Foreign Exchange," In Rudiger Dornbusch and Jacob A. Frenkel (eds.), International Economic Policy: Theory and Evidence. Baltimore: Johns Hopkins University Press, 1979.

Mckinnon, Ronald I. "Floating Foreign Exchange Rates 1973-74: The Emperor's New Clothes." In Karl Brunner and Allan Meltzer (eds.), Institutional Arrangements and the Inflation Problem, Vol. 3 of the Carnegie-Rochester Conference Series on Public Policy, A Supplementary Series to the Journal of Monetary Economics, 1976 , pp. $79-114$.

Mudd, Douglas, R. "Do Rising U.S. Interest Rates Imply a Stronger Dollar?" Federal Reserve Bank of St. Louis Review, 61, No. 6 (June, 1979): 9-13.

Mussa, Michae1, (1976a) "The Exchange Rate, the Balance of Payments and Monetary and Fiscal Policy under a Regime of Controlled Floating." Scandinavian Journal of Economics 78, No. 2 (May 1976): 229-48. Reprinted in J. A. Frenkel and H. G. Johnson (eds.), The Economics of Exchange Rates: Selected Studies. Reading, Mass.: AddisonWesley, 1978 .

(1976b) "Our Recent Experience with Fixed and Flexible Exchange Rates: A Comment." In Karl Brunner and Allan Meltzer (eds.), Institutional Arrenagements and the Inflation Problem, Vol. 3 of the Carnegie-Rochester Conference Series on Public Policy, a supplementary series to the Journal of Monetary Economics, 1976 , pp. $123-41$.

., "Exchange Rate Uncertainty: Causes, Consequences, and Policy Implications. "Unpublished manuscript, University of Chicago, 1977. 
Mussa, Michael, (1979a) "Empirical Regularities in the Behavior of Exchange Rates and Theories of the Foreign Exchange Market." Vol. 11 of the Carnegie-Rochester Conference Series on Public Polfcy, a supplementary series to the Journal of Monetary Economics, 1979, Pp. 9-57.

- (1979b) "Anticipatory Adjustment of a Floating Exchange Rate." Unpublished manuscript, University of Chicago, 1979.

- (1979c) "The Role of the Trade Balance in Exchange Rate Dynamics," Unpublished Manuscript, 1979.

Obstfeld, Maurice. "Expectations and Efficiency in the Foreign Exchange Market," unpublished paper, Massachusetts Institute of Technology, 1978.

Rodriguez, Carlos A. "The Role of Trade Flows in Exchange Rate Determination: A Rational Expectations Approach," Unpublished manuscript, Columbia University, 1978.

Saidi, Nasser, "Rational Expectations, Purchasing Power Parity and the Business Cycle" Unpublished manuscript, University of Chicago, 1977.

Shiller, Robert J., "Do Stock Prices Move Too Much to be Justified by Subsequent Changes in Dividends?" Unpublished manuscript, University of Pennsylvania, 1979. 